\title{
Review on Natural Preservatives for Extending Fish Shelf Life
}

\author{
Jun Mei ${ }^{1,2,3,4} \mathbb{D}$, Xuan Ma ${ }^{1}$ and Jing Xie ${ }^{1,2,3,4, *}$ \\ 1 College of Food Science and Technology, Shanghai Ocean University, Shanghai 201306, China \\ 2 National Experimental Teaching Demonstration Center for Food Science and Engineering Shanghai \\ Ocean University, Shanghai 201306, China \\ 3 Shanghai Engineering Research Center of Aquatic Product Processing and Preservation, \\ Shanghai 201306, China \\ 4 Shanghai Professional Technology Service Platform on Cold Chain Equipment Performance and Energy \\ Saving Evaluation, Shanghai 201306, China \\ * Correspondence: jxie@shou.edu.cn; Tel.: +86-21-61900351
}

Received: 2 September 2019; Accepted: 11 October 2019; Published: 13 October 2019

\begin{abstract}
Fish is extremely perishable as a result of rapid microbial growth naturally present in fish or from contamination. Synthetic preservatives are widely used in fish storage to extend shelf life and maintain quality and safety. However, consumer preferences for natural preservatives and concerns about the safety of synthetic preservatives have prompted the food industry to search natural preservatives. Natural preservatives from microorganisms, plants, and animals have been shown potential in replacing the chemical antimicrobials. Bacteriocins and organic acids from bacteria showed good antimicrobial activities against spoilage bacteria. Plant-derived antimicrobials could prolong fish shelf life and decrease lipid oxidation. Animal-derived antimicrobials also have good antimicrobial activities; however, their allergen risk should be paid attention. Moreover, some algae and mushroom species can also provide a potential source of new natural preservatives. Obviously, the natural preservatives could perform better in fish storage by combining with other hurdles such as non-thermal sterilization processing, modified atmosphere packaging, edible films and coatings.
\end{abstract}

Keywords: natural preservatives; fish; spoilage mechanisms; application

\section{Introduction}

Fish has high protein content and low saturated fat content, which is considered as highly valuable food [1]. In particular, fish is the primary dietary source of omega-3 polyunsaturated fatty acid (PUFA), including docosahexaenoic acid (DHA) and eicosapentaenoic acid (EPA), both of which are well-known for the anti-inflammatory action and protective effects on cardiovascular disease [2-4]. The World Health Organization (WHO) recommends a regular fish consumption of 1-2 servings per week to provide the equivalent of 200-500 mg of omega-3 PUFA [5,6]. According to statistics, fresh and live fish account for about half of the total seafood consumed by human beings. The word "fresh" refers to fish that have not been frozen, including still alive fish as well as kept in the cold but not frozen section or packed in modified atmosphere [7]. Unlike frozen fish, the fresh fish cannot stay as inventory for one month [8]. For consumers, freshness is also often associated with safety, reassurance and superior taste. In most cases, the customers believe that the fish sold in market in China are caught recently. However, it could take more than a week to arrive at these stores. Consumers are still unsure whether the "fresh" product is really fresh or has been frozen and then thawed $[9,10]$.

Fresh fish can easily deteriorate after being captured due to the endogenous enzyme and rapid microbial growth naturally present in fish or from contamination [11]. In the process of fish decay, 
decomposition of various components and formation of new compounds occur. What is more, changes in composition during fish decay lead to protein degradation and lipid oxidation, as well as changes in fish odor, flavor, and texture. Therefore, it has become inevitable to develop effective treatment methods to extend the shelf life of fish [12]. Soft or mushy texture of fish limits the shelf life, thereby impeding its marketing. During postmortem handling and storage, the holding temperature, oxygen, endogenous or microbial proteases, moisture can result in detrimental changes in the color, odor, texture, and flavor of fish $[13,14]$. Therefore, fish have traditionally been cooled and stored in flake ice, refrigerated sea water, or ice slurries or they have been preserved by exposure to chemical agents. At the same time, the fishery industry is always looking for new preservation methods to extend the fish shelf life and provide consumers with the best quality in terms of sensory and nutritional levels [15].

In recent years, researchers have put much effort into searching natural preservatives that could inhibit the growth of bacteria and fungi in food. Meanwhile, a growing number of consumers are aware of the potential negative health effects of chemical preservatives, which has prompted the food industry to find natural products used and developed as alternatives. Natural preservatives are available from a variety of sources including plants, animals, bacteria, algae, and fungi $[16,17]$. Microbial derived preservatives (e.g., bacteriocin), plant derived preservatives (thyme essential oil, tea polyphenols, rosemary extract, etc.), and animal derived preservatives (e.g., chitosan from crab or shrimp shells) have been demonstrated to have antimicrobial or antioxidant properties. In addition, antimicrobial compounds produced by algae and fungal (mushroom) could be served as potential sources of new antimicrobial substances for use as natural preservatives in food. The aims of this review were to expound the factors affecting the quality of fish by introducing the corruption mechanisms of these products and summarize natural preservatives derived from microbial-, plant-, animal-derived compounds, algae and mushrooms.

\section{Spoilage Mechanisms}

Fish is extremely perishable compared to other muscle foods and will enter into rigor mortis where fish lose their flexibility due to the stiffening of their muscle just a few hours after death [18]. Studies show that the spoilage of fish results from three basic factors: enzymatic autolysis, oxidation, and microbial growth [19].

\subsection{Autolytic Enzymatic Spoilage}

As the degradation process of fish begins with autolytic enzymatic spoilage, chemical and biological changes take place in dead fish shortly after capture due to autolytic enzymatic breakdown of major molecules. The autolytic enzymes had a significant impact on textural deterioration (softening) and therefore on spoilage; however, they did not produce the characteristic spoilage off-flavors and off-odors $[20,21]$. Some studies have demonstrated that the fish quality could deteriorate even though comparatively low levels of autolytic degradation were present and limit the shelf life of fish [22,23].

Some gastrointestinal digestion enzymes as well as endogenous muscular enzymes are found in the viscera and muscle of fish after being caught. These enzymes can be conducive to postmortem degradation in fish muscle and fish products during processing and storage, which can lead to a sensory or product associated change. On the other hand, the autolysis of fish muscle proteins could also result in fish meat spoilage and biogenic amines production. The degree of fish freshness has to be determined in the autolysis stage before the spoilage of fish begins [21]. It has been pointed out that low temperature and $\mathrm{a}_{\mathrm{w}}$ kept during the storage period can maintain a low activity of the endogenous autolytic enzymes in muscle [24]. In addition, the temperature of vacuum-packed cold-smoked salmon storage should be at low temperature to maintain low native enzyme activity in the tissue [25]. 


\subsection{Oxidative Spoilage}

Lipid oxidation could result in spoilage and deterioration and contained a three-stage free radical mechanism: initiation, propagation, and termination [26-28]. Some studies suggested that lipid oxidation in fish may be initiated and propagated by a number of mechanisms including auto-oxidation, lipoxygenase, microsomal enzymes, photosensitized oxidation, and peroxidase [29]. In addition, iron-bound proteins in fish muscles, such as hemoglobin, ferritin, myoglobin, hemosiderin, and transferrin, as well as other metals, may be released during storage and play an important role in initiating and/or activating lipid oxidation [30].

Lipid oxidation can be divided into enzymatic and non-enzymatic oxidation, both of which can result in serious decreases in fish qualities. It is typically recognized that oxidation involves the reaction of oxygen with the double bonds of fatty acids. Fish is rich in unsaturated fatty acids and prooxidant molecules, which are extremely susceptible to oxidation resulting in rancidity development and quality loss [31]. These compounds result in deteriorations of smell, color, texture, and nutritional values. Lipid oxidation products also have been demonstrated to promote protein denaturation, modification of protein electrophoretic profiles, nutritional losses, endogenous antioxidant systems losses, and developments of fluorescent compounds [32]. Accordingly, lipid oxidation leads to a decrease of fish acceptability by consumers [33].

\subsection{Microbial Spoilage}

Fish has high contents of free amino acids, a high post mortem $\mathrm{pH}$, high water contents, and many fish species contain trimethylamine oxide (TMAO), which promote bacterial growth in a wide temperature range [34]. The microbial growth is considered to be the major cause of the deterioration of fish quality, causing up to $25-30 \%$ loss of such products [17]. It is generally believed that each fish has its unique flora, which is determined by raw materials, processing parameters, subsequent storage conditions, and microbial tolerance to storage conditions [35]. For example, it was reported that spoilage microorganisms for aerobically stored frozen fish including salmon were species within the genera Shewanella (S.) and Pseudomonas (P.), while the $\mathrm{CO}_{2}$-resistant Photobacterium (Ph.) phosphoreum dominated on fish under modified atmosphere packaging [34-36].

It is important to distinguish non-spoilage bacteria from spoilage ones as many of the bacteria present do not actually contribute to spoilage during fish storage [37]. A variety of psychrotrophic Gram-negative bacteria comprise the main part of the initial microbiota of fish from temperate sea waters. However, only a small fraction of fish microbiota is responsible for spoilage, known as specific spoilage organisms (SSOs). The SSOs could dominate and produce the metabolites through assimilation of nonprotein-nitrogen of fish muscle with unpleasant and unacceptable off-flavors, which directly affect the organoleptic properties of fish resulting in its rejection by the consumers [38]. The SSOs were different for different fish species and preservation conditions. Research studies demonstrated that Pseudomonas spp. was the SSOs for Atlantic salmon (Salmo salar) in modified atmosphere packaging and bighead carp (Aristichthys nobilis) with 2\% salt, whereas Aeromonas was the SSOs for unsalted bighead carp [39].

\section{Natural Preservatives for Fish}

Fresh fish is highly perishable, and even if it can be refrigerated or frozen to extend its shelf life, these processes may not be sufficient to prevent lipid oxidation, rancidity or bacterial growth. In most cases, it is also necessary to improve the quality of fish [40]. For this reason, it is required that preservatives should be properly added to fish during storage.

With the rapid development of social economy, the application of natural preservatives in food has attracted more and more attention from the public. Generally, the public will choose a food with no preservatives, but if these are not available, the same consumer will choose a food containing natural preservatives over synthetic ones [41]. Natural preservatives guarantee that the food is free 
of microorganisms and safe to eat. Ideally, natural preservatives should have broad bactericidal and fungicidal activities, be non-toxic, be active at low concentrations, impart no flavor or color to food, have no pharmaceutical applications, label friendly, and finally cost effective [42]. Natural preservatives generally come from three sources: microorganisms, animals, and plants. In addition, various bio-active compounds extracted from algae, mushrooms and so on can also provide a potential source of new natural preservatives in the food industry [43].

\subsection{Microbial-Derived Compounds}

Specific strains of lactic acid bacteria (LAB) produce some inhibitory substances (such as diacetyl, reutericyclin), antifungal compounds (such as phenyl-lactate, propionate, cyclic dipeptides, hydroxyphenyl-lactate, and 3-hydroxy fatty acid), bacteriocins, and bacteriocin-like inhibitory substances, which have antibacterial activity and can be exploited against spoilage bacteria and food-borne pathogens in fish during storage [44]. Some applications of microbial-derived compounds in fish preservation are depicted in Table 1.

\subsubsection{Bacteriocins}

Some studies have demonstrated that bacteriocins generally produced by LAB could be active against other relatively closely-related bacteria to obtain a competitive advantage of nutrients in the environment [45]. Bacteriocins are a group of potent antimicrobial peptides containing about 30-60 amino acids, forming amphiphilic helices, which differ in activity spectrum, mode of action, biochemical characteristics, molecular weight, and genetic origin. Bacteriocin-producing LAB strains could protect themselves from their own toxins by expressing a specific immunity protein, encoded in the bacteriocin operon [46,47]. It is generally recognized that bacteriocins can be categorized into four classes: I): lantibiotics, low molecular weight $(<5 \mathrm{kDa})$ thermostable peptides, characterized by the presence of lanthionine and derivatives; II): small thermostable peptides ( $<10 \mathrm{kDa})$ composed of three subclasses: IIa (pediocin and enterocini), IIb (lactocin G), and IIc (lactocin B); III): high molecular weight (>30 kDa) thermolabile peptides, represented by helveticin J; and IV): large peptides complexed with lipids or carbohydrates [48-50].

Nisin was discovered by Rogers and Whittier in 1928, and was produced by certain strains of L. lactis subsp. Nisin structurally is a 34-amino acid polypeptide with a molar mass of $3500 \mathrm{Da}$ and belongs to the lantibiotic class as containing methyllanthionine and lanthionine groups. Nisin has been industrially produced for specific applications to prevent spore germination and pathogen growth on the surface of contaminated food. It has been accepted for commercial application as a Generally Regarded as Safe (GRAS) food preservative by around 50 countries [51,52]. Nisin Z has higher solubility and diffusion characteristics, which plays an important role in the preservation of fish [53]. According to Sofra et al., nisin $\left(2 \times 10^{4} \mathrm{IU} / 100 \mathrm{~g}\right)$ in the osmotic solution delayed tuna slices spoilage and extended shelf life to 51 days at $5{ }^{\circ} \mathrm{C}$ [54]. Nisin at $1000 \mathrm{IU} / \mathrm{g}$ obviously decreased the Listeria population in the storage days [55]. Besides, nisin had a positive effect on color stability of rainbow trout during storage as the formation of hydrophobic bonds between carotenoids and the apolar fraction of nisin [51]. Nisin exhibits good antimicrobial activities against a wide range of Gram-positive bacteria and it may be useful against some Gram-negative bacteria together with other preservatives for fish storage. Nisin combined with chitosan treatment was a promising approach to maintain quality for large or small yellow croaker [56,57]. Some studies also showed that nisin combined with natural antioxidant (such as rosemary extract, essential oil or tea polyphenols) could effectively maintain or improve the sensory attributes, inhibit the microbial growth, delay the chemical changes in the fresh fish during storage and may be a promising method to maintain the storage quality [58-61]. In addition, nisin with some non-thermal processing can also extend the shelf life of fish, such as irradiation, vacuum packaged, and so on [62-64].

Pediocins, belonging to Class IIa bacteriocins, are small, cationic proteins with anti-Listeria activity. They share a highly conserved charged and hydrophilic charged N-terminal part containing the 
consensus sequence -YGNGV- and a more variable hydrophobic and/or amphiphilic C-terminal part. Pediocins exhibit important technological properties, such as maintaining activity over a wide $\mathrm{pH}$ range and thermostability, as well as antimicrobial effect on Gram-positive food spoilage and pathogenic bacteria, making them as an important class of biopreservatives for fish $[65,66]$. Yin et al. investigated the biopreservative effectiveness of pediocin ACCEL on refrigerated fresh fish fillets. Pediocin ACCEL was more effective than nisin on the suppression of Listeria monocytogenes growth in refrigerated fish during refrigeration [67]. It is typically known that occurrence and growth of L. monocytogenes in ready-to-eat fish remains a challenge, and Listeria outbreaks have previously been reported due to fish contamination [68]. These studies demonstrated that Pediococcus acidilactici ALP57, isolated from non-fermented shellfish (oyster, mussels, clams), could synthesize pediocin bac ALP57 (approximately $6.5 \mathrm{kDa}, 12,800 \mathrm{AU} / \mathrm{mL}$ ) that has the antimicrobial activity against L. monocytogenes ESB54 during its exponential growth phase [69].

Lacticin is another bacteriocin produced by L. lactis subsp. Lactis is a two-peptide bacteriocin possessing potent activity against Gram-positive bacteria [70]. However, it is worth noting that lacticin differs from nisin in its target specificity and greater effectiveness. In addition, the mechanism of action contrasts from the single nisin peptide as requiring the interaction of two peptides for optimal bactericidal activity [71]. Kim et al. showed that the lacticin NK24 could slow down the microbial growth on packaged fresh oysters and maintain the chemical quality and extended shelf life significantly as well [72].

\subsubsection{Reuterin}

Reuterin is considered as a D-ribose analogue and is an intermediate compound generated by Lactobacillus reuteri during glycerol metabolism. It inhibits the substrate binding subunit B1 of ribonucleotide reductase, which catalyzes the reduction of ribonucleotides to their corresponding deoxyribonucleotides to inhibit DNA synthesis [73,74]. Due to its chemical properties and its antibacterial activity against food-borne pathogens and spoilage bacteria, reuterin has high potential as a food preservative [75]. As reported by Montiel et al., purified reuterin (10 AU/g) significantly inhibited L. monocytogenes growth in cold-smoked salmon kept under moderate or strong temperature abuse conditions [76]. Furthermore, reuterin together with high hydrostatic pressure at $450 \mathrm{MPa}$ for 5 min also improved the safety and extend the shelf life of cold-smoked salmon [77]. Some studies have demonstrated that reuterin has higher antimicrobial activity against Gram-negative bacteria than that of Gram-positive ones [43]. Although the antimicrobial mechanism has not yet been fully understood, so far, reuterin is still considered to be a highly promising food bio-preservative.

Table 1. Survey of literature dealing with bacteriocin employed biopreservation of fish.

\begin{tabular}{cccc}
\hline Product & Bacteriocin Employed & Reported Effects & References \\
\hline Skinless blue shark steak & Pediocin ACCEL & L. monocytogenes $\downarrow 1$ & {$[67]$} \\
Oysters, mussels, clams & BacALP7, bacALP57 & L. monocytogenes $\downarrow$, L. innocua $\downarrow$ & {$[69]$} \\
Cold-smoked salmon & Divercin V41 & L. monocytogenes $\downarrow$ & {$[78,79]$} \\
Fresh salmon fillets & Bacteriocin produced by & A. hydrophila $\downarrow$, L. monocytogenes $\downarrow$ & {$[80]$} \\
Reef cod & Lb. pentosus 39 & The total viable count $\downarrow$ & {$[81]$} \\
Reef cod & Bacterocin CD1 & The total count of spoilage bacteria $\downarrow$ & {$[82]$} \\
Pangasius fish fillets & Bacteriocin 7293 & Target microorganisms $\downarrow$ & {$[83]$} \\
Reef cod filets & Bacteriocin GP1 & Similar effect with that of sodium & {$[84]$} \\
Fish pâté using fresh & benzoate and the nisin B440 & {$[85]$} \\
Nile tilapia & Bacteriocin produced by & Vibrio $\downarrow$ & {$[86]$} \\
Fresh hake paste & Bacteriocin produced by & Native flora of fish paste $\downarrow$ & \\
\hline
\end{tabular}

${ }^{1}$ Inhibited or decreased. 


\subsubsection{Organic Acids}

Organic acids are organic compounds with one or more carboxyl groups (-COOH) in their structure and are known to possess antimicrobial properties in food application and have been studied extensively, and they are categorized as GRAS [87]. Application of organic acids on fish surfaces, mainly through dipping or spraying, is a widely-used and well-known practice. A range of experiments have shown that organic acids and their respective salts could inhibit bacterial growth in different varieties of fish. For example, García-Soto et al. suggested that the presence of lactic $(0.50 \mathrm{~g} / \mathrm{L})$ and citric $(1.25 \mathrm{~g} / \mathrm{L})$ acids in the ice medium led to a deteriorative activity inhibition and improve the quality of megrim and hake during the on-board chilled storage [88]. A novel citric, ascorbic, and lactic acid (at $800 \mathrm{mg} / \mathrm{kg}$, respectively) icing system were proved to be an effective mixture for hake, megrim, and angler preservation due to its antimicrobial effect [15]. However, the direct addition of citric acid may negatively affect the texture and other sensory attributes of fish patties. Encapsulated citric acid could minimize secondary oxidation values regardless of the concentration, which represents an appropriate strategy in the fish preservation [89]. Besides, sodium salts of the low molecular weight organic acids, such as acetic, citric, and lactic acids, have also been used to control microorganism growth, improve sensory properties, and extend the shelf life of fish. The combination of citric acid and potassium sorbate was sufficiently effective in inhibiting microorganism growth and maintaining volatile base nitrogen at low levels for the fish preservation [90]. Sallam concluded that dipping of salmon slices in aqueous solutions (2.5\%) of sodium lactate, sodium acetate, and sodium citrate could effectively inhibit the proliferation of spoilage microorganisms to delay lipid oxidation and extend the shelf life during cold storage [91]. Organic acids and salt have pleasant taste without being too tough, which can be employed for the marinated fish preservation. Frozen fillets of sardine were used to make marinades in $14 \%$ sodium chloride and $7 \%$ acetic acid in barrels for 22 days at $4{ }^{\circ} \mathrm{C}$ [92]. However, when fillets of sardine immersed in the marination solutions containing $10 \%$ sodium chloride and $2 \%$ or $4 \%$ acetic acid for $24 \mathrm{~h}$, the trimethylamine (TMA-N) and total volatile base nitrogen (TVB-N) values significantly increased during storage [93].

\subsection{Plant-Derived Compounds}

\subsubsection{Essential Oils (EOs)}

EOs are complex mixtures of volatile organic compounds (VOCs) produced as secondary metabolites in plants and frequently responsible for the characteristic odor of plants [94]. They are characterized by two or three major VOCs at fairly high concentrations (20-70\%) compared to other VOCs [95]. Some EOs have antimicrobial and antioxidant properties and an increasing demand for natural preservatives has led to EOs as potential alternatives for antimicrobials and antioxidants [96]. EOs have been proved to be effective antimicrobials against some foodborne pathogens including S. Typhimurium, E. coli O157: H7, Campylobacter, L. monocytogenes, S. aureus, and others. Studies show that the efficacy of EOs depends on chemical structure, concentration, matching the antimicrobial activity spectrum with the target microorganism(s), interactions with the food matrix, and application method [97].

It has been observed that some EOs show inhibitory effect on membrane integrity against the tested food-borne pathogenic bacteria [98-101] (Figure 1). Intracellular material leakage is a general phenomenon results in cell death. The hydrophobic nature of EOs could interfere with bacterial lipid membrane resulting in increased permeability of the cell constituents [102,103], which is in agreement with other phenolic compounds [104-107]. So far, most studies concerning the antimicrobial action mode of EOs have been carried out on bacteria, while less is known about their effects on molds and yeast. Gram-positive bacteria are generally more susceptible than Gram-negative ones [108]. The cell wall lipopolysaccharides (LPS) of Gram-negative bacteria can create a barrier toward macromolecules and hydrophobic compounds, preventing active compounds in EOs reaching to cytoplasmic membrane [109]. The combinations of EOs with other natural preservatives or even other chemical ones also show positive effects. 


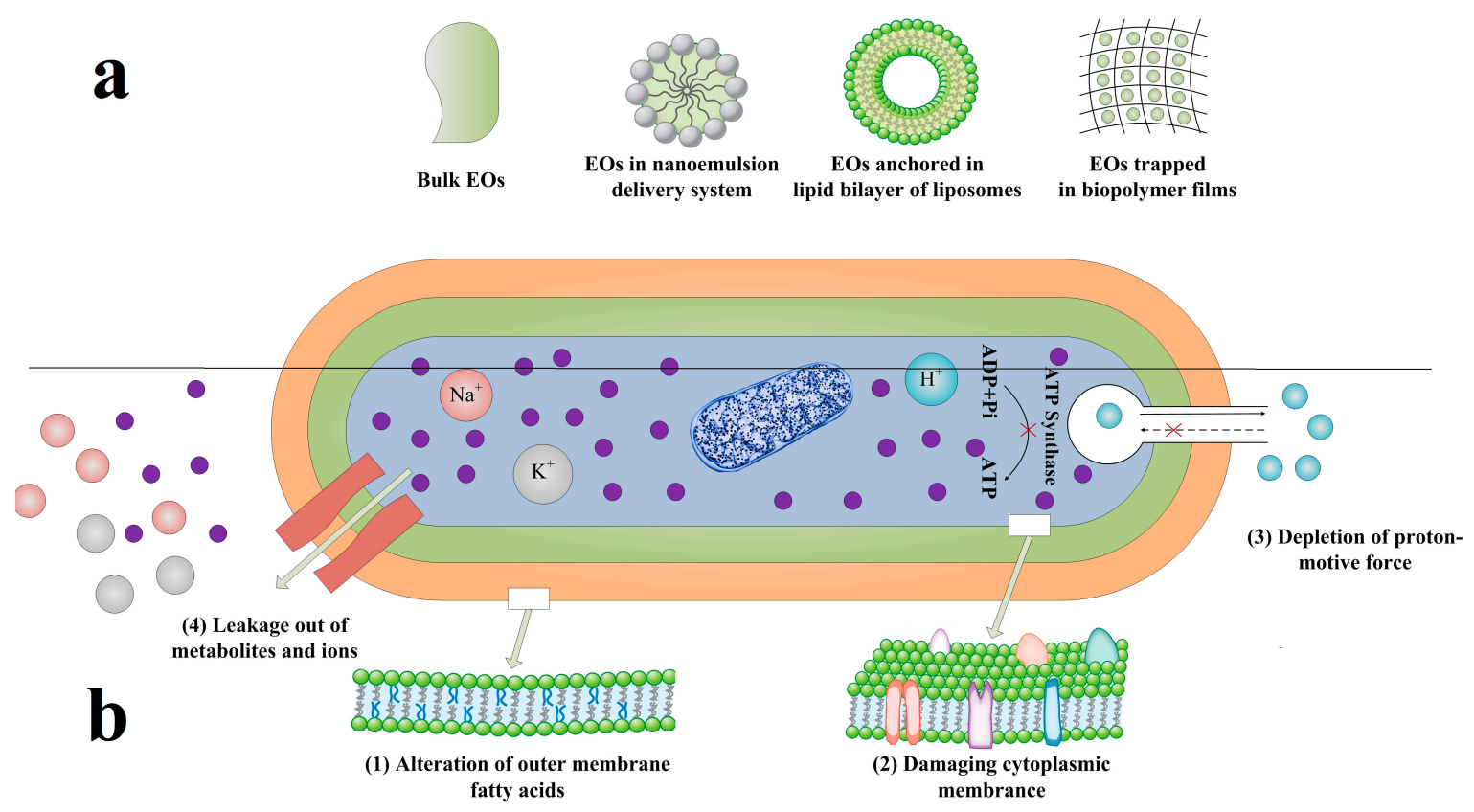

Figure 1. (a) Bulk EOs and different types of EO delivery systems, including nanoemulsion, liposomes, and biopolymer films; (b) Proposed common mechanisms of action and target sites of essential oils (EOs) or EO delivery systems on bacterial cell [110].

\subsubsection{Plant Extracts}

Plant extracts have broad application prospects in fish preservation. The antimicrobial activities of plant extracts may be attributed to the combined effects of polyphenols adsorption to bacterial membrane with membrane disruption and subsequent cellular contents leakage, and the generation of hydroperoxides from polyphenols [111-114]. Plant extracts also show antifungal activities, antioxidant, antimutagenic activities, and inhibit lipid oxidation in food [115-118]. Numerous studies have been done in-vitro to evaluate the antimicrobial activities of plant extracts; however, only a few studies are available for fish preservation as the antimicrobial activity of plant extracts does not produce as marked inhibition as many of the chemical preservatives in fish. The plant crude extracts generally contain flavonoids in the form of glycosides, in which the sugar presenting in them decreases the effectiveness against some food-borne pathogens [119,120].

The antimicrobial and antioxidant effects of various plant-derived compounds on fish have been performed and summarized in Table 2. The plant-derived compounds could extend fish shelf life by reducing the total aerobic plate count and retarding lipid oxidation and may also be used together with other natural preservatives or different packaging ways [120]. Rainbow trout (Oncorhynchus mykiss) using turmeric extract, shallot extract, and their combination with vacuum packaging could reduce the growth of total viable count and extend the shelf life [121]. The plant-derived compounds are also combined with nisin to extend the shelf life of fish and fish products [55,61,122].

\subsubsection{Natural Wood Smoke}

Natural wood smoke is a suspension of vapors, liquid droplets, and solid particles and produced by controlled wood smoldering without oxygen or at reduced oxygen levels. Different woods' smoke have different antimicrobial properties as the woods generate different levels of antimicrobials, such as organic acids, phenols, and carbonyls during pyrolysis. Now, more than 20 different kinds natural wood smoke including redwood, black walnut, hickory, birch, white oak, aspen, chestnut, and cherry have been evaluated the antimicrobial properties against $A$. hydrophila, and S. aureus [123]. Additionally, the smoke treatment could increase redness of the fish muscle and stabilized it during frozen storage [124]. It should be noted that wood smoke contains some harmful compounds, such as 
polycyclic aromatic hydrocarbons (PAHs) [125,126]. Since the 1970s, liquid smoke has been developed and become popular resulting from the concern of potentially carcinogenic benzopyrenes [127]. Liquid smoke preparations can be either incorporated as a surface additive during post thermal processing or a formula ingredient during batter mixing to reduce or eliminate food-borne pathogens as well as impart desired smoky flavor to the products. Many studies have been focused on the use of liquid smoke as a postlethality dip or spray treatment to reduce or eliminate food-borne pathogens on fish products. Antimicrobial efficacy of liquid smoke can be enhanced by vacuum-packaging, essential oils, and $\mathrm{NaCl}$ [128-132]. Also, wood smoke can be converted into nanocapsules using chitosan and surface contact area could be increased, which delayed microbial growth in fish fillets at cold storage conditions $[133,134]$.

Table 2. Application of plant-derived natural preservatives in fish and other seafood.

\begin{tabular}{|c|c|c|c|}
\hline Preservatives & Product Tested & Quality Attributes & References \\
\hline Thyme essential oil & Minced silver carp fish & L. monocytogenes viable count $\downarrow^{1}$ & [55] \\
\hline Cinnamon oil & $\begin{array}{l}\text { Northern snakehead fish } \\
\text { fillets }\end{array}$ & $\begin{aligned} \text { Bacterial growth } \downarrow, & \text { TVB-N }{ }^{2} \downarrow \text {, thiobarbituric } \\
& \text { acid } \downarrow\end{aligned}$ & [135] \\
\hline Basil leaf essential oil & Sea bass slices & Total volatile base $\downarrow$, peroxide value $\downarrow$, TBARS ${ }^{3} \downarrow$ & [136] \\
\hline $\begin{array}{l}\text { Carvacrol and thymol } \\
\text { essential oil }\end{array}$ & Carp fillets & lipid oxidation $\downarrow$, shelf life $\uparrow$ & [137] \\
\hline Cinnamon oil & Rainbow trout & Microbial growth $\downarrow$ & [138] \\
\hline $\begin{array}{l}\text { Cinnamon, oregano and } \\
\text { thyme essential oils }\end{array}$ & Salmon, scampi & Yeasts and molds $\downarrow$, shelf life $\uparrow^{4}$ & [139] \\
\hline Clove essential oil & Sardine patties & Lipidic auto-oxidation $\downarrow$, total mesophiles $\downarrow$ & [140] \\
\hline Spearmint essential oil & Red drum fillets & $\begin{array}{c}\text { Tissue hardness } \uparrow \text {, protein degradation } \downarrow \text {, } \\
\text { nucleotide breakdown } \downarrow \text {, microbiological } \\
\text { properties } \downarrow\end{array}$ & [141] \\
\hline Rosemary essential oil & Silver carp & $\begin{array}{l}\text { Lipid oxidation } \downarrow \text {, total viable and } \\
\text { psychrotrophic count } \downarrow\end{array}$ & [142] \\
\hline Horsemint essential oil & Bigheadcarp fillets & $\begin{array}{l}\text { TVB-N } \downarrow \text {, lipid oxidation } \downarrow \text {, microbial } \\
\text { deterioration } \downarrow\end{array}$ & [143] \\
\hline Oregano essential oil & Grass carp muscle & Total aerobic plate count $\downarrow$, TVB-N $\downarrow$ & [144] \\
\hline Oregano essential oil & Sea bream & TBARS $\downarrow$ & [145] \\
\hline $\begin{array}{l}\text { Oregano and thyme } \\
\text { essential oils }\end{array}$ & Rainbow trout fillets & Shelf life $\uparrow$ & [146] \\
\hline $\begin{array}{l}\text { Zataria multiflora Boiss. } \\
\quad \text { essential oil }\end{array}$ & Rainbow trout fillets & $\begin{array}{l}\text { TVB-N } \downarrow \text {, total viable bacteria } \downarrow \text {, lactic acid } \\
\text { bacteria } \downarrow \text {, Pseudomonas spp. } \downarrow\end{array}$ & [147] \\
\hline Tea polyphenol & Golden pomfret & Myofibril nanostructure $\uparrow$, spoilage $\downarrow$ & [148] \\
\hline Clove essential oil & Flounder fillets & $\begin{array}{c}\text { Total volatile bases } \downarrow, \mathrm{pH} \downarrow, \mathrm{H}_{2} \mathrm{~S} \text {-producing } \\
\text { microorganisms } \downarrow\end{array}$ & [149] \\
\hline Clove essential oil & Bluefin tuna fillets & Microbial growth $\downarrow$, lipid autooxidation $\downarrow$ & [150] \\
\hline Cinnamon essential oil & Common carp & TVB-N $\downarrow$, biogenic amines $\downarrow$ & [151] \\
\hline Oregano essential oil & Fish fillets & Microbial growth $\downarrow$, shelf life $\uparrow$ & [152] \\
\hline Cinnamon bark oil & Grass carp fillets & $\begin{array}{c}\text { Shelf life } \uparrow, \text { Aeromonas, Shewanella, and } \\
\text { Pseudomonas } \downarrow\end{array}$ & [153] \\
\hline Eucalyptus essential oil & Silver carp fillets & $\begin{array}{l}\text { Total viable counts } \downarrow \text {, total psychrotrophic } \\
\text { counts } \downarrow \text {, TVB- } N \downarrow \text {, shelf life } \uparrow\end{array}$ & [154] \\
\hline Oregano essential oil & Grass carp & $\begin{array}{c}\text { TBARS } \downarrow \text {, TVB-N } \downarrow \text {, putrescine } \downarrow \text {, hypoxanthine } \downarrow \text {, } \\
\text { Aeromonas and Shewanella } \downarrow\end{array}$ & [155] \\
\hline Potato peel extract & Minced horse mackerel & Lipid and protein oxidation $\downarrow$ & [156] \\
\hline $\begin{array}{l}\text { Quince polyphenolic } \\
\text { extract }\end{array}$ & Mackerel fillets & $\begin{array}{c}\text { Fish oil oxidative deterioration } \downarrow \text {, food-borne } \\
\text { bacteria } \downarrow\end{array}$ & [157] \\
\hline $\begin{array}{c}\text { Rosemary, sage tea } \\
\text { extract }\end{array}$ & Sardine fillets & $\begin{array}{l}\text { Histamine, putrescine and cadaverine } \\
\text { accumulation } \downarrow\end{array}$ & [158] \\
\hline $\begin{array}{l}\text { Grape seed and clove } \\
\text { bud extracts }\end{array}$ & Silver carp fillets & Lipid and protein oxidation $\downarrow$ & [159] \\
\hline $\begin{array}{l}\text { Rosemary extract and } \\
\text { onion juice }\end{array}$ & Sardine mince & Lipid oxidation $\downarrow$ & [160] \\
\hline Rosemary extract & Crucian carp & TVB-N $\downarrow, K$-value $\downarrow$, TBARS $\downarrow$ & [161] \\
\hline Grape polyphenols & Horse mackerel fillets & Lipid oxidation $\downarrow$ & [162] \\
\hline
\end{tabular}


Table 2. Cont.

\begin{tabular}{|c|c|c|c|}
\hline Preservatives & Product Tested & Quality Attributes & References \\
\hline $\begin{array}{l}\text { Tea polyphenol, } \\
\text { rosemary extract }\end{array}$ & Large yellow croaker & Maintained the good quality, shelf life $\uparrow$ & [163] \\
\hline Tea polyphenol & $\begin{array}{l}\text { Golden pomfret fish } \\
\text { fillets }\end{array}$ & $\begin{array}{c}\text { Troponin T degradation } \downarrow \text {, spoilage VOCs }{ }^{5} \downarrow \text {, } \\
\text { aerobic mesophilic/psychrotrophic count } \downarrow \text {, } \\
\text { yeasts and moulds } \downarrow\end{array}$ & [148] \\
\hline Tomato plant extract & Sierra fish fillets & $\begin{array}{l}\text { ATP-related compounds } \downarrow \text {, K value } \downarrow \text {, pH } \downarrow \text {, } \\
\text { total mesophilic count } \downarrow \text {, shelf life } \uparrow\end{array}$ & [164] \\
\hline Pomegranate peel extract & Rainbow trout & $\begin{array}{c}\text { Microbial growth } \downarrow \text {, sensory and textural } \\
\text { properties } \uparrow\end{array}$ & [165] \\
\hline Grape seed extract & Tilapia fillets & Trimethylamine $\downarrow$, histidine $\downarrow$ & [166] \\
\hline Pomegranate rind extract & Mackerel mince & $\begin{array}{l}\text { Protein oxidation } \downarrow \text {, carbonyl content } \downarrow \text {, } \\
\text { sulphydryl content } \uparrow \text {, protein solubility } \downarrow\end{array}$ & [167] \\
\hline $\begin{array}{l}\text { Shallot fruit and ajwain } \\
\text { seed extracts }\end{array}$ & Rainbow trout fillets & $\begin{array}{c}\text { Lipid oxidation } \downarrow \text {, microbial spoilage } \downarrow \text {, shelf } \\
\text { life } \uparrow \text {, sensory quality } \uparrow\end{array}$ & [168] \\
\hline $\begin{array}{l}\text { Black cumin, black } \\
\text { caraway extracts }\end{array}$ & Silver carp & $\begin{array}{c}\text { Psychotropic bacteria } \downarrow \text {, total viable counts } \downarrow \text {, } \\
\text { lipid oxidation } \downarrow\end{array}$ & [169] \\
\hline $\begin{array}{l}\text { Pistachio green hull } \\
\text { extract }\end{array}$ & Rainbow trout & $\begin{array}{l}\text { Oxidative and hydrolytic rancidity } \downarrow, \mathrm{pH} \downarrow \text {, } \\
\text { TVB-N } \downarrow \text {, histamine } \downarrow\end{array}$ & [166] \\
\hline Rosemary extract & Grass carp & $\begin{array}{l}\text { Lipid oxidation } \downarrow \text {, growth of bacteria } \downarrow \text {, } \\
\text { organoleptic quality } \uparrow \text {, shelf life } \uparrow\end{array}$ & [170] \\
\hline Quinoa ethanolic extract & Atlantic chub mackerel & $\begin{array}{l}\text { Lipid oxidation } \downarrow \text {, lipid hydrolysis } \downarrow, \mathrm{pH} \downarrow \text {, } \\
\text { trimethylamine values } \downarrow\end{array}$ & [171] \\
\hline Grape seed extract & Tilapia fillets & $\begin{array}{c}\text { Protein oxidation } \downarrow \text {, maintained the morphology } \\
\text { of myofibrils, freshness } \uparrow\end{array}$ & [172] \\
\hline Pomegranate peel extract & Nile tilapia fillets & $\begin{array}{c}\text { Microbial counts } \downarrow \text {, TVB- } \mathrm{\downarrow} \downarrow \text {, peroxide value } \downarrow \text {, } \\
\text { TBARS } \downarrow \text {, sensory evaluation } \uparrow\end{array}$ & [173] \\
\hline Mint extract & Indian mackerel & Microbial proliferation $\downarrow$, shelf life $\uparrow$ & [174] \\
\hline $\begin{array}{l}\text { Allium paradoxum and } \\
\text { Eryngium caucasicum } \\
\text { extracts }\end{array}$ & Silver carp fillets & $\begin{array}{l}\text { Peroxide value } \downarrow \text {, TBARS } \downarrow \text {, acid value } \downarrow \text {, } \\
\text { TVB-N } \downarrow \text {, bacterial growth } \downarrow\end{array}$ & [175] \\
\hline Fennel extract & Silver carp fillets & $\begin{array}{c}\text { TVB-N } \downarrow \text {, peroxide value } \downarrow \text {, TBARS } \downarrow \text {, microbial } \\
\text { deterioration } \downarrow \text {, shelf life } \uparrow\end{array}$ & [176] \\
\hline Urtica dioica L. extract & Rainbow trout fillets & Bacterial growth $\downarrow$, TVB-N $\downarrow$, TBARS $\downarrow$ & [177] \\
\hline Pomegranate peel extract & Bighead carp fillets & $\begin{array}{c}\text { Sensory quality } \uparrow \text {, flesh color } \uparrow \text {, spoilage } \\
\text { bacteria } \downarrow \text {, biogenic amines } \downarrow \text {, ATP-related } \\
\text { compounds } \downarrow \text {, K-value } \downarrow\end{array}$ & [178] \\
\hline Summer savory extract & Spangled emperor fillets & $\begin{array}{c}\text { Microbial growth } \downarrow \text {, lipid oxidation } \downarrow \text {, protein } \\
\text { degradation } \downarrow \text {, texture hardness } \uparrow \text {, sensory } \\
\text { properties } \uparrow\end{array}$ & [179] \\
\hline
\end{tabular}

${ }^{1}$ Inhibited or decreased; ${ }^{2}$ Total volatile base nitrogen; ${ }^{3}$ Thiobarbituric acid reactive substances; ${ }^{4}$ Improved or increased; ${ }^{5}$ Volatile organic chemicals.

\subsubsection{Algae and Mushrooms}

As natural sources of bioactive compounds, algae and mushrooms have a wide range of biological activities including antimicrobial, antioxidant, antiviral, anti-inflammatory, and other health promoting benefits [94,180-184]. Among the major bioactive ingredients of algae and mushrooms with demonstrated antimicrobial activities, proteins, antioxidants (polyphenols, flavonoids, and carotenoids), polyunsaturated fatty acids, and polysaccharides are the most important ones [185]. Until now, the antimicrobial potential of algae and mushrooms has been generally tested in vitro, providing reliable quantitative estimates of minimum inhibitory concentration (MIC) values for many samples [185,186]. Compounds reported to be present in algae included phlorotannins, terpenoids, phenolic compounds, acrylic acid, steroids, cyclic polysulphides, halogenated ketones and alkanes, and fatty acids that act as bactericidal agents [187]. The presence of these compounds suggests alternative mechanisms for antimicrobial action. For example, phlorotannins could inhibit the oxidative phosphorylation and bind with bacterial proteins including enzymes and cell membranes, leading to cell lysis [188]. The mechanisms of sulphated polysaccharides and algal polysaccharides may be related to glycoprotein receptors on the cell surface of polysaccharides which bind with compounds in the cell wall, cytoplasmic membrane, and DNA, increasing the cytoplasmic membrane permeability, protein leakage, and binding 
of bacterial DNA [189]. The antimicrobial activities of mushrooms may be related to a variety of secondary metabolites with biological activity, such as gallic acids, some phenols, volatile compounds, free fatty acids, and their derivatives [190]. Considering the wide biodiversity of mushrooms, they could easily become accessible sources of natural preservatives. However, few studies have evaluated the antimicrobial activities of algae and mushrooms in fish preservation.

\subsubsection{Saponinse}

Saponins are natural glycosides compounds in some plants showing promising results as a broad-spectrum antimicrobial and antifungal activities [191,192]. The antifungal activity of saponins interacts with cytoplasmic membrane sterols, the ergosterol, can provoke pores and loss of membrane integrity, resulting in cell death [193].

\subsubsection{Flavonoids}

Flavonoids are ubiquitous in photosynthesizing cells and are commonly found in some plant parts. They exhibit broad-spectrum antimicrobial activities due to the ability to form complexes with extracellular and soluble proteins as well as with bacterial membranes [194-196]. Flavonoids have antimicrobial activities against bacteria and the hydroxyls at special sites on the aromatic rings of flavonoids improve the activity. However, the methylation of the active hydroxyl groups generally decreases the activity. The hydrophobic substituents such as prenyl groups, alkylamino chains, alkyl chains, and nitrogen or oxygen containing heterocyclic moieties usually enhance the activity for all the flavonoids [197]. As a whole, it is necessary to further investigate their potential use as food preservatives as people are increasingly interested in finding more natural alternatives.

\subsection{Animal-Derived Compounds}

At present, many animal-derived antimicrobial compounds have also been used for fish preservation. Such examples include chitosan from shellfish, lactoperoxidase, and lactoferrin from milk, and lysozymes from hen eggs [198]. However, one of the major problems associated with animal-derived antimicrobials is their allergen risk; the sources of such ingredients are often allergen-containing foods including shellfish, milk, and egg [199].

\subsubsection{Chitosan}

Chitosan is a polycation biopolymer that naturally exists in the exoskeletons of arthropods and crustaceans [200]. Chitosan is the $N$-deacetylated form of chitin and linear polysaccharides with a variable degree of $N$-acetylation composed of more than $80 \% \beta-(1,4)$-2-amino-d-glucopyranose and less than $20 \% \beta$-(1,4)-2-acetamido-d-glucopyranose [201]. Chitosan and its derivatives have the characteristic of biodegradability, biocompatibility, bioadhesion, and nontoxicity, making it valuable compounds for medical, food, agricultural applications, and waste water treatment [30]. Chitosan has an excellent inhibitory effect on various microorganisms including some bacteria and fungi, and the antimicrobial action is intrinsically influenced by the type of chitosan, polymerization degree, natural nutrient constituency, host, nutrient or chemical composition of the substrates or both, and the environmental conditions (e.g., substrate water activity, moisture or both) [202-204]. Besides, chitosan has a novel application in the form of edible biopolymer-based films for bioactive compounds to extend shelf life of fish due to their abilities to retard oxygen, moisture, solute transports, and aromas [204]. More recently, some reviews have reported the application of chitosan as a bioactive film used in food including fish preservation [30,204-210].

\subsubsection{Lysozyme}

Lysozyme is an enzyme naturally found in mammalian milk and poultry eggs and is usually considered as a safety additive added directly to food [211]. It plays an important role in mediating 
protection against microbial invasion and the egg-white lysozyme is the most commercially available form of lysozyme [212]. Lysozyme could separate the $\beta(1 \rightarrow 4)$ bond between $\mathrm{N}$-acetylglucosamine and $\mathrm{N}$-acetyl-wall acid in the cell wall peptidoglycan of Gram-positive bacteria resulting in preventing them from invading. As reported by Rawdkuen et al., lysozyme has the highest antimicrobial activity against S. cerevisia and Listeria; however, it has no significant effect on Gram-negative bacteria because of the lipopolysaccharidic layer of outer membrane served as a physical barrier [213].

The outer membrane of Gram-negative bacteria could be destabilized by nisin or EDTA and the antimicrobial spectrum of lysozyme significantly increases [214]. Combination of $1000 \mathrm{IU} / \mathrm{g}$ of nisin and $160 \mu \mathrm{g} / \mathrm{mL}$ of oyster lysozyme treatment inside the calcium alginate coating could effectively retain the antimicrobial activity for 35 days [215]. Shi et al. used lysozyme to improve the quality of fresh pomfret preservation and lysozyme could inhibit the growth of Gram-positive bacteria and extended the shelf life by 1 to 2 days [216]. Wu et al. reported the utilization of chitosan-lysozyme coating could inhibit the microbial growth and lipid oxidation, maintain sensory qualities and extend the shelf life of refrigerated large yellow croaker [217]. The collagen-lysozyme active coatings could inhibit the microbial growth and decrease the total volatile basic nitrogen values on preserving fresh salmon fillets [218]. Besides, the lysozyme-enhanced bioactive films appeared to increase slightly in water vapor permeability [219].

\subsubsection{Lactoferrin}

Lactoferrin is an $80 \mathrm{kDa}$ whey glycoprotein consisting of two homologous globular lobes (N-lobe and C-lobe), and each of which binds an iron atom $\left(\mathrm{Fe}^{2+}\right.$ or $\left.\mathrm{Fe}^{3+}\right)$ in synergy with the binding of one carbonate ion [220]. The antimicrobial activity of lactoferrin consists of two different and unrelated mechanisms, one on account of iron deprivation inhibiting the microbial growth, and the other associated with the large cationic patches presenting on the surface of lactoferrin [221]. Lactoferrin exhibits antimicrobial activity against a wide variety of bacteria and apolactoferrin was found to be bactericidal for $V$. cholerae and S. mutans, but not for E. coli. Further studies have demonstrated that lactoferrin has bactericidal effect only when in its iron-free state and that iron-saturated lactoferrin has a reduced antimicrobial activity [222]. Lactoferrin has been widely reported for its application as an adjuvant to improve cellular immune responses of fish [223-225]. However, few studies are available on its use in fish preservation.

\subsubsection{Lactoperoxidase}

Lactoperoxidase is a member of the peroxidase family and the content of bovine milk is higher than that of other mammals' milk [226]. Bovine lactoperoxidase is a glycoprotein consisting of a single peptide chain with a molecular weight of about 78.4 KDa and can catalyze the oxidation of thiocyanate ion (SCN-) in lactoperoxidase, generating oxidizing products such as hypothiocyanous acid (HOSCN) and hypothiocyanite (OSCN-). These products are known as antimicrobial agents that inhibit microbial growth by the oxidation of sulphydryl (SH) groups of microbial enzymes and other proteins [227-229]. Lactoperoxidase generally exhibits antimicrobial activity against Gram-negative bacteria, and the spoilage microorganisms of refrigerated fish have been considered to be caused by some Gram-negative bacteria, particularly P. fluorescens and S. putrefaciens [230]. Shokri et al. showed $1.25 \%(v / v)$ lactoperoxidase treated trout fillets could extend a shelf life by 4 days during storage; however, lipid oxidation in the fillets was not significantly affected by lactoperoxidase treatment [231]. Some studies used the active coatings incorporated with lactoperoxidase to improve the fish quality and extend the shelf life during storage $[227,232,233]$. At the same time, lactoperoxidase may also work in coordination with other natural preservatives or processing methods. For example, high hydrostatic pressure treatment at $450 \mathrm{MPa}$ for $10 \mathrm{~min}$ combined with lactoperoxidase had good antimicrobial effects against $L$. monocytogenes, which could void biogenic amine formation for smoked salmon and prolong the shelf life [234]. In addition, Sharifi et al. indicated that lactoperoxidase combined with 
Zataria multiflora Boiss essential in alginate solution had a stronger effect on inhibiting the growths of E. coli $\mathrm{O}_{157}: \mathrm{H}_{7}$ and L. monocytogenes in trout fillets [235].

\section{Conclusions}

Microbial-, plant-, and animal-derived natural preservatives were summarized for fish preservation. Nisin, pediocins, reuterin, and lacticin as bacteriocins and organic acids and their sodium produced by microorganisms have been assessed in fish preservation and have shown antimicrobial activities against food-borne pathogens. The plant-derived compounds, including essential oils, plant extracts, and wood smoke, show excellent antimicrobial and/or antioxidant activities in fish preservation. Animal-derived antimicrobials including chitosan, lysozymes, lactoferrin, and lactoperoxidase have yet been evaluated and demonstrated to extend the shelf life of fish. In addition, the rich diversity of different algae and mushroom species can provide potential sources of new natural antimicrobial agents. It is evident that natural preservatives combined with either lower levels of synthetic/chemical ones, or with other hurdles, such as non-thermal sterilization processing, modified atmosphere packaging, and edible films and coatings, will enhance the performance of various natural preservatives discussed in the review.

Author Contributions: J.M. conceptualized the idea and wrote the introduction. X.M. prepared all figures using the TIFF format. J.M., X.M., and J.X. wrote Natural Preservatives for Fish, Spoilage Mechanisms, and Conclusion sections, respectively. All authors read, revised, and approved the review article for publication.

Funding: The authors gratefully acknowledge the funding from National Natural Science Foundation of China (31972142, 31601414), China Agriculture Research System (CARS-47).

Conflicts of Interest: The authors declare no conflict of interest.

\section{References}

1. EFSA Panel on Dietetic Products, Nutrition and Allergies. Scientific Opinion on health benefits of seafood (fish and shellfish) consumption in relation to health risks associated with exposure to methylmercury. EFSA J. 2016, 12, 3761.

2. Vilavert, L.; Borrell, F.; Nadal, M.; Jacobs, S.; Minnens, F.; Verbeke, W.; Marques, A.; Domingo, J.L. Health risk/benefit information for consumers of fish and shellfish: Fish Choice, a new online tool. Food Chem. Toxicol. 2017, 104, 79-84. [CrossRef] [PubMed]

3. Siscovick, D.S.; Barringer, T.A.; Fretts, A.M.; Wu, J.H.; Lichtenstein, A.H.; Costello, R.B.; Krisetherton, P.M.; Jacobson, T.A.; Engler, M.B.; Alger, H.M. Omega-3 polyunsaturated fatty acid (fish oil) supplementation and the prevention of clinical cardiovascular disease: A science advisory from the American heart association. Circulation 2017, 135, e867-e884. [CrossRef] [PubMed]

4. Nestel, P.; Clifton, P.; Colquhoun, D.; Noakes, M.; Mori, T.A.; Sullivan, D.; Thomas, B. Indications for omega-3 long chain polyunsaturated fatty acid in the prevention and treatment of cardiovascular disease. Heart Lung Circ. 2015, 24, 769-779. [CrossRef] [PubMed]

5. Tediosi, A.; Fait, G.; Jacobs, S.; Verbeke, W.; Álvarez-Muñoz, D.; Diogene, J.; Reuver, M.; Marques, A.; Capri, E. Insights from an international stakeholder consultation to identify informational needs related to seafood safety. Environ. Res. 2015, 143, 20-28. [CrossRef]

6. Wallin, A.; Di Giuseppe, D.; Orsini, N.; Åkesson, A.; Forouhi, N.G.; Wolk, A. Fish consumption and frying of fish in relation to type 2 diabetes incidence: A prospective cohort study of Swedish men. Eur. J. Nutr. 2015, 56, 843-852. [CrossRef]

7. Mcmanus, A.; Hunt, W.; Storey, J.; Mcmanus, J.; Hilhorst, S. Perceptions and preference for fresh seafood in an Australian context. Int. J. Consum. Stud. 2014, 38, 146-152. [CrossRef]

8. Hicks, D.T. Seafood safety and quality: The consumer's role. Foods 2016, 5, 71. [CrossRef]

9. Wakamatsu, H.; Miyata, T. A demand analysis for the Japanese cod markets with unknown structural changes. Fish. Sci. 2015, 81, 393-400. [CrossRef]

10. Bruhn, C.M. Consumer Acceptance of High-Pressure Processed Products: American Perspective; Springer: New York, NY, USA, 2016. 
11. Jiang, D.; Liu, Y.; Jiang, H.; Rao, S.; Fang, W.; Wu, M.; Yuan, L.; Fang, W. A novel screen-printed mast cell-based electrochemical sensor for detecting spoilage bacterial quorum signaling molecules (N-acyl-homoserine-lactones) in freshwater fish. Biosen. Bioelectron. 2018, 102, 396-402. [CrossRef]

12. Campos, C.A.; Castro, M.P.; Aubourg, S.P.; Velázquez, J.B. Novel Technologies in Food Science; Springer: New York, NY, USA, 2012.

13. Sriket, C.; Benjakul, S.; Visessanguan, W.; Kishimura, H. Collagenolytic serine protease in fresh water prawn (Macrobrachium rosenbergii): Characteristics and its impact on muscle during iced storage. Food Chem. 2010, 124, 29-35. [CrossRef]

14. Sriket, C. Proteases in fish and shellfish: Role on muscle softening and prevention. Int. Food Res. J. 2014, 21, 433-445.

15. Rey, M.S.; Garcíasoto, B.; Fuertesgamundi, J.R.; Aubourg, S.; Barrosvelázquez, J. Effect of a natural organic acid-icing system on the microbiological quality of commercially relevant chilled fish species. LWT-Food Sci. Technol. 2012, 46, 217-223. [CrossRef]

16. Ghanbari, M.; Jami, M.; Domig, K.J.; Kneifel, W. Seafood biopreservation by lactic acid bacteria-A review. LWT-Food Sci. Technol. 2013, 54, 315-324. [CrossRef]

17. Hassoun, A.; Çoban, Ö.E. Essential oils for antimicrobial and antioxidant applications in fish and other seafood products. Trends Food Sci. Technol. 2017, 68, 26-36. [CrossRef]

18. Hong, H.; Regenstein, J.M.; Luo, Y. The importance of ATP-related compounds for the freshness and flavor of post-mortem fish and shellfish muscle: A review. Crit. Rev. Food Technol. 2015, 57, 1787-1798. [CrossRef] [PubMed]

19. Ghaly, A.E.; Dave, D.; Budge, S.; Brooks, M.S. Fish spoilage mechanisms and preservation techniques: Review. Am. J. Appl. Sci. 2010, 7, 859-877. [CrossRef]

20. Lyhs, U.; Lahtinen, J.; Schelvissmit, R. Microbiological quality of maatjes herring stored in air and under modified atmosphere at 4 and $10^{\circ} \mathrm{C}$. Food Microbiol. 2007, 24, 508-516. [CrossRef]

21. Ocañohiguera, V.M.; Maedamartínez, A.N.; Marquezríos, E.; Canizalesrodríguez, D.F.; Castilloyáñez, F.J.; Ruízbustos, E.; Gracianoverdugo, A.Z.; Plascenciajatomea, M. Freshness assessment of ray fish stored in ice by biochemical, chemical and physical methods. Food Chem. 2011, 125, 49-54. [CrossRef]

22. Lakshmanan, R.; Piggott, J.R.; Paterson, A. Potential applications of high pressure for improvement in salmon quality. Trends Food Sci. Technol. 2003, 14, 354-363. [CrossRef]

23. Sumar, S.; Fraser, O.P. Compositional changes and spoilage in fish (part II)-Microbiological induced deterioration. Nutr. Food Sci. 1998, 98, 325-329.

24. Pachecoaguilar, R.; Lugosanchez, M.E.; Roblesburgueno, M.R. Postmortem biochemical and functional characteristic of monterey sardine muscle stored at $0{ }^{\circ} \mathrm{C}$. J. Food Sci. 2010, 65, 40-47. [CrossRef]

25. Dondero, M.; Cisternas, F.; Carvajal, L.; Simpson, R. Changes in quality of vacuum-packed cold-smoked salmon (Salmo salar) as a function of storage temperature. Food Chem. 2004, 87, 543-550. [CrossRef]

26. Fraser, O.; Sumar, S. Compositional changes and spoilage in fish-an introduction. Nutr. Food Sci. 1998, 98, 275-279. [CrossRef]

27. Shahidi, F.; Botta, J.R. Seafoods: Chemistry, Processing Technology and Quality; Springer: New York, NY, USA, 1994.

28. Frankel, E.N. Chemistry of free radical and singlet oxidation of lipids. Prog. Lipid Res. 1984, $23,197-221$. [CrossRef]

29. Hsieh, R.J.; Kinsella, J.E. Oxidation of polyunsaturated fatty acids: Mechanisms, products, and inhibition with emphasis on fish. Adv. Food Nutr. Res. 1989, 33, 233-341.

30. Alishahi, A.; Aïder, M. Applications of chitosan in the seafood industry and aquaculture: A review. Food Bioprocess Technol. 2012, 5, 817-830. [CrossRef]

31. Losada, V.; Barros-Velázquez, J.; Aubourg, S.P. Rancidity development in frozen pelagic fish: Influence of slurry ice as preliminary chilling treatment. LWT-Food Sci. Technol. 2007, 40, 991-999. [CrossRef]

32. Lugasi, A.; Losada, V.; Hóvári, J.; Lebovics, V.; Jakóczi, I.; Aubourg, S. Effect of pre-soaking whole pelagic fish in a plant extract on sensory and biochemical changes during subsequent frozen storage. LWT-Food Sci. Technol. 2007, 40, 930-936. [CrossRef]

33. Beck, C. Effects of high pressure processing on lipid oxidation: A review. Innov. Food Sci. Emerg. Technol. 2014, 22, 1-10. 
34. Chaillou, S.; Chaulot-Talmon, A.; Caekebeke, H.; Cardinal, M.; Christieans, S.; Denis, C.; Desmonts, M.H.; Dousset, X.; Feurer, C.; Hamon, E. Origin and ecological selection of core and food-specific bacterial communities associated with meat and seafood spoilage. ISME J. 2015, 9, 1105-1118. [CrossRef] [PubMed]

35. Møretrø, T.; Moen, B.; Heir, E.; Hansen, A.A.; Langsrud, S. Contamination of salmon fillets and processing plants with spoilage bacteria. Int. J. Food Microbiol. 2016, 237, 98-108. [CrossRef] [PubMed]

36. Murhekar, S.; Wright, M.H.; Greene, A.C.; Brownlie, J.C.; Cock, I.E. Inhibition of Shewanella spp. growth by Syzygium australe and Syzygium luehmannii extracts: Natural methods for the prevention of fish spoilage. J. Food Sci. Technol. 2017, 54, 3314-3326. [CrossRef] [PubMed]

37. Huss, H.H. Quality and Quality Changes in Fresh Fish; FAO: Rome, Italy, 1995.

38. Boziaris, I.S.; Parlapani, F.F. The Microbiological Quality of Food; Woodhead Publishing: Sawston, UK, 2017.

39. Liu, X.; Zhang, Y.; Li, D.; Luo, Y. Characterization of the microbiota in lightly salted bighead carp (Aristichthys nobilis) fillets stored at $4{ }^{\circ} \mathrm{C}$. Food Microbiol. 2017, 62, 106-111. [CrossRef] [PubMed]

40. Erkan, N.; Doğruyol, H.; Günlü, A.; Genç, İ.Y. Use of natural preservatives in seafood: Plant extracts, edible film and coating. J. Food Health Sci. 2015, 1, 33-49. [CrossRef]

41. Carocho, M.; Barreiro, M.F.; Morales, P.; Ferreira, I.C.F.R. Adding molecules to food, pros and cons: A review on synthetic and natural food additives. Compr. Rev. Food Sci. Food Safety 2014, 13, 377-399. [CrossRef]

42. Carocho, M.; Morales, P.; Ferreira, I.C.F.R. Natural food additives: Quo vadis? Trends Food Sci. Technol. 2015, 45, 284-295. [CrossRef]

43. Gyawali, R.; Ibrahim, S.A. Natural products as antimicrobial agents. Food Control 2014, 46, 412-429. [CrossRef]

44. Gálvez, A.; Abriouel, H.; Benomar, N.; Lucas, R. Microbial antagonists to food-borne pathogens and biocontrol. Curr. Opin. Biotechnol. 2010, 21, 142-148. [CrossRef] [PubMed]

45. Johnson, M.E.M.; Jung, Y.G.; Jin, Y.Y.; Jayabalan, R.; Yang, S.H.; Suh, J.W. Bacteriocins as food preservatives: Challenges and emerging horizons. Crit. Rev. Food Sci. 2017, 58, 2743-2767. [CrossRef]

46. Mokoena, M.P. Lactic acid bacteria and their bacteriocins: Classification, biosynthesis and applications against uropathogens: A mini-review. Molecules 2017, 22, 1255. [CrossRef] [PubMed]

47. Chikindas, M.L.; Weeks, R.; Drider, D.; Chistyakov, V.A.; Dicks, L.M. Functions and emerging applications of bacteriocins. Curr. Opin. Biotechnol. 2017, 49, 23-28. [CrossRef] [PubMed]

48. Klaenhammer, T.R. Genetics of bacteriocins produced by lactic acid bacteria. FEMS Microbiol. Rev. 1993, 12, 39-85. [CrossRef] [PubMed]

49. Balciunas, E.M.; Martinez, F.A.; Todorov, S.D.; de Melo Franco, B.D.; Converti, A.; de Souza Oliveira, R.P. Novel biotechnological applications of bacteriocins: A review. Food Control 2013, 32, 134-142. [CrossRef]

50. Cotter, P.D.; Hill, C.; Ross, R.P. Bacteriocins: Developing innate immunity for food. Nat. Rev. Microbiol. 2005, 3, 777-788. [CrossRef] [PubMed]

51. Chaves, C.L.; Serio, A.; Montalvo, C.; Ramirez, C.; Peréz, J.Á.; Paparella, A.; Mastrocola, D.; Martuscelli, M. Effect of nisin on biogenic amines and shelf life of vacuum packaged rainbow trout (Oncorhynchus mykiss) fillets. J. Food Sci. Technol. 2017, 54, 3268-3277. [CrossRef] [PubMed]

52. Gharsallaoui, A.; Oulahal, N.; Joly, C.; Degraeve, P. Nisin as a food preservative: Part 1: Physicochemical properties, antimicrobial activity, and main uses. Crit. Rev. Food Sci. 2016, 56, 1262-1274. [CrossRef] [PubMed]

53. Arauz, L.J.D.; Jozala, A.F.; Mazzola, P.G.; Penna, T.C.V. Nisin biotechnological production and application: A review. Trends Food Sci. Technol. 2009, 20, 146-154. [CrossRef]

54. Sofra, C.; Tsironi, T.; Taoukis, P.S. Modeling the effect of pre-treatment with nisin enriched osmotic solution on the shelf life of chilled vacuum packed tuna. J. Food Eng. 2017, 216, 125-131. [CrossRef]

55. Abdollahzadeh, E.; Rezaei, M.; Hosseini, H. Antibacterial activity of plant essential oils and extracts: The role ofthyme essential oil, nisin, and their combination to control Listeria monocytogenes inoculated in minced fish meat. Food Control 2014, 35, 177-183. [CrossRef]

56. Hui, G.; Wei, L.; Feng, H.; Jian, L.; Gao, Y. Effects of chitosan combined with nisin treatment on storage quality of large yellow croaker (Pseudosciaena crocea). Food Chem. 2016, 203, 276-282. [CrossRef] [PubMed]

57. Wu, T.; Wu, C.; Fang, Z.; Ma, X.; Chen, S.; Hu, Y. Effect of chitosan microcapsules loaded with nisin on the preservation of small yellow croaker. Food Control 2017, 79, 317-324. [CrossRef]

58. Yang, A.; Cheng, F.; Tong, P.; Chen, H. Effect of tea polyphenol and nisin on the quality of tortoise (Trachemys scripta elegans) meat during chilled storage. J. Food Process. Preserv. 2017, 41, e13308. [CrossRef] 
59. Ju, J.; Wang, C.; Qiao, Y.; Li, D.; Li, W. Effects of tea polyphenol combined with nisin on the quality of weever (Lateolabrax japonicus) in the initial stage of fresh-frozen or chilled storage state. J. Aquat. Food Prod. Technol. 2017, 26, 543-552. [CrossRef]

60. Roomiani, L.; Soltani, M.; Basti, A.A.; Mahmoodi, A. Effect of Rosmarinus officinalis essential oil and nisin on Streptococcus iniae and Lactococcus garvieae in a food model system. J. Aquat. Food Prod. Technol. 2017, 26, 1189-1198. [CrossRef]

61. Gao, M.; Feng, L.; Jiang, T.; Zhu, J.; Fu, L.; Yuan, D.; Li, J. The use of rosemary extract in combination with nisin to extend the shelf life of pompano (Trachinotus ovatus) fillet during chilled storage. Food Control 2014, 37, 1-8. [CrossRef]

62. Kakatkar, A.S.; Gautam, R.K.; Shashidhar, R. Combination of glazing, nisin treatment and radiation processing for shelf-life extension of seer fish (Scomberomorous guttatus) steaks. Radiat. Phys. Chem. 2017, 130, 303-305. [CrossRef]

63. Behnam, S.; Anvari, M.; Rezaei, M.; Soltanian, S.; Safari, R. Effect of nisin as a biopreservative agent on quality and shelf life of vacuum packaged rainbow trout (Oncorhynchus mykiss) stored at $4{ }^{\circ} \mathrm{C}$. J. Food Sci. Technol. 2015, 52, 2184-2192. [CrossRef]

64. Lebow, N.K.; Desrocher, L.D.; Younce, F.L.; Zhu, M.J.; Ross, C.F.; Smith, D.M. Influence of high-pressure processing at low temperature and nisin on Listeria innocua survival and sensory preference of dry-cured cold-smoked salmon. J. Food Sci. 2017, 82, 2977-2986. [CrossRef]

65. Papagianni, M.; Anastasiadou, S. Pediocins: The bacteriocins of Pediococci. Sources, production, properties and applications. Microb. Cell Fact. 2009, 8, 3. [CrossRef]

66. Porto, M.C.; Kuniyoshi, T.M.; Po, D.S.D.A.; Vitolo, M.; Rp, D.S.O. Pediococcus spp.: An important genus of lactic acid bacteria and pediocin producers. Biotechnol. Adv. 2017, 35, 361-374. [CrossRef] [PubMed]

67. Yin, L.J.; Chienwei, W.U.; Jiang, S.T. Biopreservative effect of pediocin ACCEL on refrigerated seafood. Fish. Sci. 2007, 73, 907-912. [CrossRef]

68. Mejlholm, O.; Bøknæs, N.; Dalgaard, P. Development and validation of a stochastic model for potential growth of Listeria monocytogenes in naturally contaminated lightly preserved seafood. Food Microbiol. 2015, 45, 276-289. [CrossRef] [PubMed]

69. Pinto, A.L.; Fernandes, M.; Pinto, C.; Albano, H.; Castilho, F.; Teixeira, P.; Gibbs, P.A. Characterization of anti-Listeria bacteriocins isolated from shellfish: Potential antimicrobials to control non-fermented seafood. Int. J. Food Microbiol. 2009, 129, 50-58. [CrossRef] [PubMed]

70. Garcíacayuela, T.; Requena, T.; Carmen, M.M.; Peláez, C. Rapid detection of Lactococcuslactis isolates producing the lantibiotics nisin, lacticin 481 and lacticin 3147 using MALDI-TOF MS. J. Microbiol. Meth. 2017, 139, 138-142. [CrossRef]

71. Draper, L.A.; Cotter, P.D.; Hill, C.; Ross, R.P. The two peptide lantibiotic lacticin 3147 acts synergistically with polymyxin to inhibit Gram negative bacteria. BMC Microbiol. 2013, 13, 212. [CrossRef] [PubMed]

72. Kim, Y.M.; Paik, H.D.; Lee, D.S. Shelf-life characteristics of fresh oysters and ground beef as affected by bacteriocin-coated plastic packaging film. J. Sci. Food Agric. 2002, 82, 998-1002. [CrossRef]

73. Rasch, M.; Métris, A.; Baranyi, J.; Bjørn, B.B. The effect of reuterin on the lag time of single cells of Listeria innocua grown on a solid agar surface at different $\mathrm{pH}$ and $\mathrm{NaCl}$ concentrations. Int. J. Food Microbiol. 2007, 113, 35-40. [CrossRef]

74. Garde, S.; Gómez-Torres, N.; Hernández, M.; Ávila, M. Susceptibility of Clostridium perfringens to antimicrobials produced by lactic acid bacteria: Reuterin and nisin. Food Control 2014, 44, 22-25. [CrossRef]

75. Fernández-Cruz, M.L.; Martín-Cabrejas, I.; Pérez-del Palacio, J.; Gaya, P.; Díaz-Navarro, C.; Navas, J.M.; Medina, M.; Arqués, J.L. In vitro toxicity of reuterin, a potential food biopreservative. Food Chem. Toxicol. 2016, 96, 155-159. [CrossRef]

76. Montiel, R.; Martín-Cabrejas, I.; Langa, S.; El Aouad, N.; Arqués, J.L.; Reyes, F.; Medina, M. Antimicrobial activity of reuterin produced by Lactobacillus reuteri on Listeria monocytogenes in cold-smoked salmon. Food Microbiol. 2014, 44, 1-5. [CrossRef] [PubMed]

77. Montiel, R.; Martín-Cabrejas, I.; Gaya, P.; Medina, M. Reuterin and high hydrostatic pressure treatments on the inactivation of Listeria monocytogenes and effect on the characteristics of cold-smoked salmon. Food Bioprocess Technol. 2014, 7, 2319-2329. [CrossRef] 
78. Brillet-Viel, A.; Pilet, M.F.; Courcoux, P.; Prévost, H.; Leroi, F. Optimization of growth and bacteriocin activity of the food bioprotective Carnobacterium divergens V41 in an animal origin protein free medium. Front. Mar. Sci. 2016, 3, 128. [CrossRef]

79. Brillet, A.; Pilet, M.F.; Prevost, H.; Bouttefroy, A.; Leroi, F. Biodiversity of Listeria monocytogenes sensitivity to bacteriocin-producing Carnobacterium strains and application in sterile cold-smoked salmon. J. Appl. Microbiol. 2004, 97, 1029-1037. [CrossRef] [PubMed]

80. Anacarso, I.; Messi, P.; Condò, C.; Iseppi, R.; Bondi, M.; Sabia, C.; Niederhäusern, S.D. A bacteriocin-like substance produced from Lactobacillus pentosus 39 is a natural antagonist for the control of Aeromonas hydrophila and Listeria monocytogenes in fresh salmon fillets. LWT-Food Sci. Technol. 2014, 55, 604-611. [CrossRef]

81. Sarika, A.R.; Lipton, A.P.; Aishwarya, M.S.; Dhivya, R.S. Efficacy of bacteriocin of Enterococcus faecalis CD1 as a biopreservative for high value marine fish reef cod (Epinephelus diacanthus) under different storage conditions. J. Microbiol. Biotechnol. Res. 2017, 1, 18-24.

82. Sarika, A.R.; Lipton, A.P.; Aishwarya, M.S.; Dhivya, R.S. Isolation of a bacteriocin-producing Lactococcus lactis and application of its bacteriocin to manage spoilage bacteria in high-value marine fish under different storage temperatures. Appl. Biochem. Biotechnol. 2012, 167, 1280-1289. [CrossRef]

83. Woraprayote, W.; Pumpuang, L.; Tosukhowong, A.; Zendo, T.; Sonomoto, K.; Benjakul, S.; Visessanguan, W. Antimicrobial biodegradable food packaging impregnated with Bacteriocin 7293 for control of pathogenic bacteria in pangasius fish fillets. LWT-Food Sci. Technol. 2018, 89, 427-433. [CrossRef]

84. Sarika, A.R.; Lipton, A.P.; Aishwarya, M.S. Biopreservative efficacy of bacteriocin GP1 of Lactobacillus rhamnosus GP1 on stored fish filets. Front. Nutr. 2019, 6, 29. [CrossRef]

85. Kaktcham, P.M.; Tchamani Piame, L.; Sandjong Sileu, G.M.; Foko Kouam, E.M.; Temgoua, J.-B.; Zambou Ngoufack, F.; de Lourdes Pérez-Chabela, M. Bacteriocinogenic Lactococcus lactis subsp. lactis 3MT isolated from freshwater Nile Tilapia: Isolation, safety traits, bacteriocin characterisation, and application for biopreservation in fish pâté. Arch. Microbiol. 2019. [CrossRef]

86. Delcarlo, S.B.; Parada, R.; Schelegueda, L.I.; Vallejo, M.; Marguet, E.R.; Campos, C.A. From the isolation of bacteriocinogenic LAB strains to the application for fish paste biopreservation. LWT-Food Sci. Technol. 2019, 110, 239-246. [CrossRef]

87. Vázquez, J.A.; González, M.P.; Murado, M.A. Effects of lactic acid bacteria cultures on pathogenic microbiota from fish. Aquaculture 2005, 245, 149-161. [CrossRef]

88. García-Soto, B.; Barros-Velázquez, J.; Aubourg, S.P. Use of citric and lactic acids in ice to enhance quality of two fish species during on-board chilled storage. Int. J. Refrig. 2014, 40, 390-397. [CrossRef]

89. Bou, R.; Claret, A.; Stamatakis, A.; Martínez, B.; Guerrero, L. Quality changes and shelf-life extension of ready-to-eat fish patties by adding encapsulated citric acid. J. Sci. Food Agric. 2017, 97, 5352-5360. [CrossRef] [PubMed]

90. Fernández-Segovia, I.; Escriche, I.; Fuentes, A.; Serra, J.A. Microbial and sensory changes during refrigerated storage of desalted cod (Gadus morhua) preserved by combined methods. Int. J. Food Microbiol. 2007, 116, 64-72. [CrossRef] [PubMed]

91. Sallam, K.I. Antimicrobial and antioxidant effects of sodium acetate, sodium lactate, and sodium citrate in refrigerated sliced salmon. Food Control 2007, 18, 566-575. [CrossRef]

92. Kilinc, B.; Cakli, S. Chemical, microbiological and sensory changes in thawed frozen fillets of sardine (Sardina pilchardus) during marination. Food Chem. 2004, 88, 275-280. [CrossRef]

93. Gökoğlu, N.; Cengız, E.; Yerlıkaya, P. Determination of the shelf life of marinated sardine (Sardina pilchardus) stored at $4{ }^{\circ} \mathrm{C}$. Food Control 2004, 15, 1-4. [CrossRef]

94. Fleita, D.; El-Sayed, M.; Rifaat, D. Evaluation of the antioxidant activity of enzymatically-hydrolyzed sulfated polysaccharides extracted from red algae; Pterocladia capillacea. LWT-Food Sci. Technol. 2015, 63, 1236-1244. [CrossRef]

95. Bakkali, F.; Averbeck, S.; Averbeck, D.; Idaomar, M. Biological effects of essential oils-A review. Food Chem. Toxicol. 2008, 46, 446-475. [CrossRef]

96. Calo, J.R.; Crandall, P.G.; O’Bryan, C.A.; Ricke, S.C. Essential oils as antimicrobials in food systems-A review. Food Control 2015, 54, 111-119. [CrossRef]

97. Tiwari, B.K.; Valdramidis, V.P.; O’Donnell, C.P.; Muthukumarappan, K.; Bourke, P.; Cullen, P.J. Application of natural antimicrobials for food preservation. J. Agric. Food Chem. 2009, 57, 5987-6000. [CrossRef] [PubMed] 
98. Wan, J.; Zhong, S.; Schwarz, P.; Chen, B.; Rao, J. Enhancement of antifungal and mycotoxin inhibitory activities of food-grade thyme oil nanoemulsions with natural emulsifiers. Food Control 2019, 106, 106709. [CrossRef]

99. Kang, J.; Jin, W.; Wang, J.; Sun, Y.; Wu, X.; Liu, L. Antibacterial and anti-biofilm activities of peppermint essential oil against Staphylococcus aureus. LWT-Food Sci. Technol. 2019, 101, 639-645. [CrossRef]

100. Zhang, L.L.; Zhang, L.F.; Hu, Q.P.; Hao, D.L.; Xu, J.G. Chemical composition, antibacterial activity of Cyperus rotundus rhizomes essential oil against Staphylococcus aureus via membrane disruption and apoptosis pathway. Food Control 2017, 80, 290-296. [CrossRef]

101. Ziaee, E.; Razmjooei, M.; Shad, E.; Eskandari, M.H. Antibacterial mechanisms of Zataria multiflora Boiss. essential oil against Lactobacillus curvatus. LWT-Food Sci. Technol. 2018, 87, 406-412. [CrossRef]

102. Hącwydro, K.; Flasiński, M.; Romańczuk, K. Essential oils as food eco-preservatives: Model system studies on the effect of temperature on limonene antibacterial activity. Food Chem. 2017, 235, 127-135. [CrossRef]

103. Wang, Y.; Zhang, Y.; Shi, Y.Q.; Pan, X.H.; Lu, Y.H.; Cao, P. Antibacterial effects of cinnamon (Cinnamomum zeylanicum) bark essential oil on Porphyromonas gingivalis. Microb. Pathog. 2018, 116, 26-32. [CrossRef]

104. Guo, L.; Sun, Q.; Gong, S.; Bi, X.; Jiang, W.; Xue, W.; Fei, P. Antimicrobial activity and action approach of the olive oil polyphenol extract against Listeria monocytogenes. Front. Microbiol. 2019, 10, 1586. [CrossRef]

105. Cui, S.; Ma, X.; Wang, X.; Zhang, T.-A.; Hu, J.; Tsang, Y.F.; Gao, M.-T. Phenolic acids derived from rice straw generate peroxides which reduce the viability of Staphylococcus aureus cells in biofilm. Ind. Crop. Prod. 2019, 140, 111561. [CrossRef]

106. Meira, N.; Holley, R.A.; Bordin, K.; Macedo, R.; Luciano, F.B. Combination of essential oil compounds and phenolic acids against Escherichia coli O157: $\mathrm{H} 7$ in vitro and in dry-fermented sausage production. Int. J. Food Microbiol. 2017, 260, 59-64. [CrossRef] [PubMed]

107. Friedman, M.; Levin, C.E.; Henika, P.R. Addition of phytochemical-rich plant extracts mitigate the antimicrobial activity of essential oil/wine mixtures against Escherichia coli O157:H7 but not against Salmonella enterica. Food Control 2017, 73, 562-565. [CrossRef]

108. Hyldgaard, M.; Mygind, T.; Meyer, R.L. Essential oils in food preservation: Mode of action, synergies, and interactions with food matrix components. Front. Microbiol. 2012, 3, 12. [CrossRef] [PubMed]

109. Wen, P.; Zhu, D.H.; Wu, H.; Zong, M.H.; Jing, Y.R.; Han, S.Y. Encapsulation of cinnamon essential oil in electrospun nanofibrous film for active food packaging. Food Control 2016, 59, 366-376. [CrossRef]

110. Rao, J.; Chen, B.; McClements, D.J. Improving the efficacy of essential oils as antimicrobials in foods: Mechanisms of action. Annu. Rev. Food Sci. Technol. 2019, 10, 365-387. [CrossRef] [PubMed]

111. Akter, S.; Netzel, M.E.; Tinggi, U.; Osborne, S.A.; Fletcher, M.T.; Sultanbawa, Y. Antioxidant rich extracts of Terminalia ferdinandiana inhibit the growth of foodborne bacteria. Foods 2019, 8, 281. [CrossRef] [PubMed]

112. Bouarab Chibane, L.; Degraeve, P.; Ferhout, H.; Bouajila, J.; Oulahal, N. Plant antimicrobial polyphenols as potential natural food preservatives. J. Sci. Food Agric. 2019, 99, 1457-1474. [CrossRef]

113. Snchez, E.; García, S.; Heredia, N. Extracts of edible and medicinal plants damage membranes of vibrio cholerae. Appl. Environ. Microb. 2010, 76, 6888-6894. [CrossRef]

114. Chew, Y.L.; Chan, E.W.L.; Tan, P.L.; Lim, Y.Y.; Stanslas, J.; Goh, J.K. Assessment of phytochemical content, polyphenolic composition, antioxidant and antibacterial activities of Leguminosae medicinal plants in Peninsular Malaysia. BMC Complem. Altern. Med. 2011, 11, 12. [CrossRef]

115. Ashrafi, A.; Jokar, M.; Mohammadi Nafchi, A. Preparation and characterization of biocomposite film based on chitosan and kombucha tea as active food packaging. Int. J. Biol. Macromol. 2018, 108, 444-454. [CrossRef]

116. Kharchoufi, S.; Licciardello, F.; Siracusa, L.; Muratore, G.; Hamdi, M.; Restuccia, C. Antimicrobial and antioxidant features of 'Gabsi' pomegranate peel extracts. Ind. Crop. Prod. 2018, 111, 345-352. [CrossRef]

117. Ghayempour, S.; Montazer, M.; Mahmoudi, R.M. Tragacanth gum as a natural polymeric wall for producing antimicrobial nanocapsules loaded with plant extract. Int. J. Biol. Macromol. 2015, 81, 514-520. [CrossRef] [PubMed]

118. Cando, D.; Morcuende, D.; Utrera, M.; Estévez, M. Phenolic-rich extracts from Willowherb (Epilobium hirsutum L.) inhibit lipid oxidation but accelerate protein carbonylation and discoloration of beef patties. Eur. Food Res. Technol. 2014, 238, 741-751. [CrossRef]

119. Kumar, S.; Pandey, A.K. Chemistry and biological activities of flavonoids: An overview. Sci. World J. 2013, 2013, 162750. [CrossRef] [PubMed] 
120. Negi, P.S. Plant extracts for the control of bacterial growth: Efficacy, stability and safety issues for food application. Int. J. Food Microbiol. 2012, 156, 7-17. [CrossRef] [PubMed]

121. Samaneh, P.; Masoud, R.; Hedayat, H. Effects of turmeric, shallot extracts, and their combination on quality characteristics of vacuum-packaged rainbow trout stored at $4 \pm 1{ }^{\circ} \mathrm{C}$. J. Food Sci. 2011, 76, M387-M391.

122. Ekhtiarzadeh, H.; Basti, A.A.; Misaghi, A.; Sari, A.; Khanjari, A.; Rokni, N.; Abbaszadeh, S.; Partovi, R. Growth response of Vibrio parahaemolyticus and Listeria monocytogenes in salted fish fillets as affected by Zataria multiflora boiss. Essential oil, nisin, and their combination. J. Food Saf. 2012, 32, 263-269. [CrossRef]

123. Lingbeck, J.M.; Cordero, P.; O’Bryan, C.A.; Johnson, M.G.; Ricke, S.C.; Crandall, P.G. Functionality of liquid smoke as an all-natural antimicrobial in food preservation. Meat Sci. 2014, 97, 197-206. [CrossRef]

124. Kristinsson, H.G.; Danyali, N.; Ua-Angkoon, S. Effect of filtered wood smoke treatment on chemical and microbial changes in mahi mahi fillets. J. Food Sci. 2007, 72, C16-C24. [CrossRef]

125. Hokkanen, M.; Luhtasela, U.; Kostamo, P.; Ritvanen, T.; Peltonen, K.; Jestoi, M. Critical effects of smoking parameters on the levels of polycyclic aromatic hydrocarbons in traditionally smoked fish and meat products in Finland. J. Chem. 2018, 2018, 2160958. [CrossRef]

126. Bomfeh, K.; Jacxsens, L.; Amoa-Awua, W.K.; Tandoh, I.; Afoakwa, E.O.; Gamarro, E.G.; Ouadi, Y.D.; De Meulenaer, B. Reducing polycyclic aromatic hydrocarbon contamination in smoked fish in the Global South: A case study of an improved kiln in Ghana. J. Sci. Food Agric. 2019, 99, 5417-5423. [CrossRef]

127. Holley, R.A.; Patel, D. Improvement in shelf-life and safety of perishable foods by plant essential oils and smoke antimicrobials. Food Microbiol. 2005, 22, 273-292. [CrossRef]

128. Chatzikyriakidou, K.; Katsanidis, E. Effect of liquid smoke dipping and packaging method on the keeping quality of raw and cooked chub mackerel (Scomber japonicus) fillets. J. Aquat. Food Prod. Technol. 2012, 21, 445-454. [CrossRef]

129. Suñen, E.; Aristimuño, C.; Fernandez-Galian, B. Activity of smoke wood condensates against Aeromonas hydrophila and Listeria monocytogenes in vacuum-packaged, cold-smoked rainbow trout stored at $4{ }^{\circ} \mathrm{C}$. Food Res. Int. 2003, 36, 111-116. [CrossRef]

130. Goulas, A.E.; Kontominas, M.G. Effect of salting and smoking-method on the keeping quality of chub mackerel (Scomber japonicus): Biochemical and sensory attributes. Food Chem. 2005, 93, 511-520. [CrossRef]

131. Kristinsson, H.G.; Crynen, S.; Yagiz, Y. Effect of a filtered wood smoke treatment compared to various gas treatments on aerobic bacteria in yellowfin tuna steaks. LWT-Food Sci. Technol. 2008, 41, 746-750. [CrossRef]

132. Rabiey, S.; Hosseini, H.; Rezaei, M. The hurdle effect of Bunium persicum essential oil, smoke and $\mathrm{NaCl}$ for controlling the Listeria monocytogenes growth in fish model systems. J. Food Safety 2013, 33, 137-144. [CrossRef]

133. Ceylan, Z.; Sengor, G.F.U.; Yilmaz, M.T. Nanoencapsulation of liquid smoke/thymol combination in chitosan nanofibers to delay microbiological spoilage of sea bass (Dicentrarchus labrax) fillets. J. Food Eng. 2018, 229, 43-49. [CrossRef]

134. Saloko, S.; Darmadji, P.; Setiaji, B.; Pranoto, Y. Antioxidative and antimicrobial activities of liquid smoke nanocapsules using chitosan and maltodextrin and its application on tuna fish preservation. Food Biosci. 2014, 7, 71-79. [CrossRef]

135. Lu, F.; Ding, Y.T.; Ye, X.Q.; Liu, D.H. Cinnamon and nisin in alginate-calcium coating maintain quality of fresh northern snakehead fish fillets. LWT-Food Sci. Technol. 2010, 43, 1331-1335. [CrossRef]

136. Arfat, Y.A.; Benjakul, S.; Vongkamjan, K.; Sumpavapol, P.; Yarnpakdee, S. Shelf-life extension of refrigerated sea bass slices wrapped with fish protein isolate/fish skin gelatin-ZnO nanocomposite film incorporated with basil leaf essential oil. J. Food Sci. Technol. 2015, 52, 6182-6193. [CrossRef] [PubMed]

137. Bsm, M.; Yamazaki, K.; Miyashita, K.; Shin, I.; Suzuki, T. A new technology for fish preservation by combined treatment with electrolyzed $\mathrm{NaCl}$ solutions and essential oil compounds. Food Chem. 2006, 99, 656-662.

138. Ojagh, S.M.; Rezaei, M.; Razavi, S.H.; Hosseini, S.M.H. Effect of chitosan coatings enriched with cinnamon oil on the quality of refrigerated rainbow trout. Food Chem. 2010, 120, 193-198. [CrossRef]

139. Haute, S.V.; Raes, K.; Meeren, P.V.D.; Sampers, I. The effect of cinnamon, oregano and thyme essential oils in marinade on the microbial shelf life of fish and meat products. Food Control 2016, 68, 30-39. [CrossRef]

140. Salgado, P.R.; Lópezcaballero, M.E.; Gómezguillén, M.C.; Mauri, A.N.; Montero, M.P. Sunflower protein films incorporated with clove essential oil have potential application for the preservation of fish patties. Food Hydrocoll. 2013, 33, 74-84. [CrossRef] 
141. Cai, L.; Cao, A.; Li, Y.; Song, Z.; Leng, L.; Li, J. The effects of essential oil treatment on the biogenic amines inhibition and quality preservation of red drum (Sciaenops ocellatus) fillets. Food Control 2015, 56, 1-8. [CrossRef]

142. Abdollahi, M.; Rezaei, M.; Farzi, G. Influence of chitosan/clay functional bionanocomposite activated with rosemary essential oil on the shelf life of fresh silver carp. Int. J. Food Sci. Technol. 2014, 49, 811-818. [CrossRef]

143. Heydari, R.; Bavandi, S.; Javadian, S.R. Effect of sodium alginate coating enriched with horsemint (Mentha longifolia) essential oil on the quality of bighead carp fillets during storage at $4{ }^{\circ} \mathrm{C}$. Food Sci. Nutr. 2015, 3, 188-194. [CrossRef]

144. Wu, J.; Ge, S.; Liu, H.; Wang, S.; Chen, S.; Wang, J.; Li, J.; Zhang, Q. Properties and antimicrobial activity of silver carp (Hypophthalmichthys molitrix) skin gelatin-chitosan films incorporated with oregano essential oil for fish preservation. Food Packaging Shelf Life 2014, 2, 7-16. [CrossRef]

145. Goulas, A.E.; Kontominas, M.G. Combined effect of light salting, modified atmosphere packaging and oregano essential oil on the shelf-life of sea bream (Sparus aurata): Biochemical and sensory attributes. Food Chem. 2007, 100, 287-296. [CrossRef]

146. Jouki, M.; Yazdi, F.T.; Mortazavi, S.A.; Koocheki, A.; Khazaei, N. Effect of quince seed mucilage edible films incorporated with oregano or thyme essential oil on shelf life extension of refrigerated rainbow trout fillets. Int. J. Food Microbiol. 2014, 174, 88-97. [CrossRef] [PubMed]

147. Raeisi, M.; Tajik, H.; Aliakbarlu, J.; Mirhosseini, S.H.; Hosseini, S.M.H. Effect of carboxymethyl cellulose-based coatings incorporated with Zataria multiflora Boiss. Essential oil and grape seed extract on the shelf life of rainbow trout fillets. LWT-Food Sci. Technol. 2015, 64, 898-904. [CrossRef]

148. Feng, X.; Ng, V.K.; Mikš-Krajnik, M.; Yang, H. Effects of fish gelatin and tea polyphenol coating on the spoilage and degradation of myofibril in fish fillet during cold storage. Food Bioprocess Technol. 2017, 10, 89-102. [CrossRef]

149. Da Rocha, M.; Alemán, A.; Romani, V.P.; López-Caballero, M.E.; Gómez-Guillén, M.C.; Montero, P.; Prentice, C. Effects of agar films incorporated with fish protein hydrolysate or clove essential oil on flounder (Paralichthys orbignyanus) fillets shelf-life. Food Hydrocoll. 2018, 81, 351-363. [CrossRef]

150. Echeverría, I.; López-Caballero, M.E.; Gómez-Guillén, M.C.; Mauri, A.N.; Montero, M.P. Active nanocomposite films based on soy proteins-montmorillonite- clove essential oil for the preservation of refrigerated bluefin tuna (Thunnus thynnus) fillets. Int. J. Food Microbiol. 2018, 266, 142-149. [CrossRef] [PubMed]

151. Zhang, Y.; Li, D.; Lv, J.; Li, Q.; Kong, C.; Luo, Y. Effect of cinnamon essential oil on bacterial diversity and shelf-life in vacuum-packaged common carp (Cyprinus carpio) during refrigerated storage. Int. J. Food Microbiol. 2017, 249, 1-8. [CrossRef]

152. Cardoso, L.G.; Pereira Santos, J.C.; Camilloto, G.P.; Miranda, A.L.; Druzian, J.I.; Guimarães, A.G. Development of active films poly (butylene adipate co-terephthalate)_PBAT incorporated with oregano essential oil and application in fish fillet preservation. Ind. Crop. Prod. 2017, 108, 388-397. [CrossRef]

153. Huang, Z.; Liu, X.; Jia, S.; Luo, Y. Antimicrobial effects of cinnamon bark oil on microbial composition and quality of grass carp (Ctenopharyngodon idellus) fillets during chilled storage. Food Control 2017, 82, 316-324. [CrossRef]

154. Valipour Kootenaie, F.; Ariaii, P.; Khademi Shurmasti, D.; Nemati, M. Effect of chitosan edible coating enriched with eucalyptus essential oil and $\alpha$-tocopherol on silver carp fillets quality during refrigerated storage. J. Food Safety 2017, 37, e12295. [CrossRef]

155. Huang, Z.; Liu, X.; Jia, S.; Zhang, L.; Luo, Y. The effect of essential oils on microbial composition and quality of grass carp (Ctenopharyngodon idellus) fillets during chilled storage. Int. J. Food Microbiol. 2018, 266, 52-59. [CrossRef]

156. Farvin, K.H.S.; Grejsen, H.D.; Jacobsen, C. Potato peel extract as a natural antioxidant in chilled storage of minced horse mackerel (Trachurus trachurus): Effect on lipid and protein oxidation. Food Chem. 2012, 131, 843-851. [CrossRef]

157. Sami, F.; Saloua, S.; Faten, R.; MouradBen, S. Damage inhibition during refrigerated storage of mackerel (Scomber scombrus) fillets by a presoaking in quince (Cydonia oblonga) polyphenolic extract. Int. J. Food Sci. Technol. 2010, 43, 2056-2064. 
158. Özogul, F.; Kuley, E.; Kenar, M. Effects of rosemary and sage tea extract on biogenic amines formation of sardine (Sardina pilchardus) fillets. Int. J. Food Sci. Technol. 2011, 46, 761-766. [CrossRef]

159. Shi, C.; Cui, J.; Yin, X.; Luo, Y.; Zhou, Z. Grape seed and clove bud extracts as natural antioxidants in silver carp (Hypophthalmichthys molitrix) fillets during chilled storage: Effect on lipid and protein oxidation. Food Control 2014, 40, 134-139. [CrossRef]

160. Serdaroğlu, M.; Felekoğlu, E. Effects of using rosemary extract and onion juice on oxidative stability of sardine (Sardina pilchardus) mince. J. Food Qual. 2005, 28, 109-120. [CrossRef]

161. Li, T.; Li, J.; Hu, W.; Zhang, X.; Li, X.; Zhao, J. Shelf-life extension of crucian carp (Carassius auratus) using natural preservatives during chilled storage. Food Chem. 2012, 135, 140-145. [CrossRef]

162. Pazos, M.; González, M.J.; Gallardo, J.M.; Torres, J.L.; Medina, I. Preservation of the endogenous antioxidant system of fish muscle by grape polyphenols during frozen storage. Eur. Food Res. Technol. 2005, 220, 514-519. [CrossRef]

163. Li, T.; Hu, W.; Liac, J.; Zhu, J.; Li, X. Coating effects of tea polyphenol and rosemary extract combined with chitosan on the storage quality of large yellow croaker (Pseudosciaena crocea). Food Control 2012, 25, 101-106. [CrossRef]

164. Ramírez-Guerra, H.E.; Castillo-Yañez, F.J.; Montaño-Cota, E.A.; Ruíz-Cruz, S.; Márquez-Ríos, E.; Canizales-Rodríguez, D.F.; Torres-Arreol, W.; Montoya-Camacho, N.; Ocaño-Higuera, V.M. Protective effect of an edible tomato plant extract/chitosan coating on the quality and shelf life of sierra fish fillets. J. Chem. 2018, 2018, 2436045. [CrossRef]

165. Berizi, E.; Hosseinzadeh, S.; Shekarforoush, S.S.; Barbieri, G. Microbial, chemical, textural and sensory properties of coated rainbow trout by chitosan combined with pomegranate peel extract during frozen storage. Int. J. Biol. Macromol. 2018, 106, 1004-1013. [CrossRef]

166. Özalp Özen, B.; Soyer, A. Effect of plant extracts on lipid and protein oxidation of mackerel (Scomber scombrus) mince during frozen storage. J. Food Sci. Technol. 2018, 55, 120-127. [CrossRef] [PubMed]

167. Raeisi, S.; Sharifi-Rad, M.; Quek, S.Y.; Shabanpour, B.; Sharifi-Rad, J. Evaluation of antioxidant and antimicrobial effects of shallot (Allium ascalonicum L.) fruit and ajwain (Trachyspermum ammi (L.) Sprague) seed extracts in semi-fried coated rainbow trout (Oncorhynchus mykiss) fillets for shelf-life extension. LWT-Food Sci. Technol. 2016, 65, 112-121. [CrossRef]

168. Eskandari, S.; Hosseini, H.; Gholamzadeh, M.; Mousavi Khaneghah, A.; Hosseini, E. The effects of black cumin, black caraway extracts and their combination on shelf life extension of silver carp (Hypophthalmichthys molitrix) during refrigerated storage. J. Food Safety 2015, 35, 154-160. [CrossRef]

169. Nazeri, F.S.; Soltanizadeh, N.; Goli, S.A.H.; Mazaheri, S. Chemical stability of rainbow trout in icing medium containing pistachio (Pistachia vera) green hull extract during chilled storage. J. Food Sci. Technol. 2018, 55, 449-456. [CrossRef] [PubMed]

170. Wu, M.; Li, C.; Du, W.; Yang, X.; Liu, Z. Preparation of chitosan/rosemary extract nanoparticles and their application for inhibiting lipid oxidation in grass carp (Ctenopharyngodon idellus) during cold storage. J. Aquat. Food Prod. Technol. 2018, 27, 759-770. [CrossRef]

171. Miranda, J.M.; Carrera, M.; Pastén, A.; Vega-Gálvez, A.; Barros-Velázquez, J.; Aubourg, S.P. The impact of quinoa (Chenopodium quinoa Willd.) ethanolic extracts in the icing medium on quality loss of Atlantic chub mackerel (Scomber colias) under chilling storage. Eur. J. Lipid Sci. Technol. 2018, 120, 1800280. [CrossRef]

172. Zhao, X.; Zhou, Y.; Zhao, L.; Chen, L.; He, Y.; Yang, H. Vacuum impregnation of fish gelatin combined with grape seed extract inhibits protein oxidation and degradation of chilled tilapia fillets. Food Chem. 2019, 294, 316-325. [CrossRef] [PubMed]

173. Alsaggaf, M.S.; Moussa, S.H.; Tayel, A.A. Application of fungal chitosan incorporated with pomegranate peel extract as edible coating for microbiological, chemical and sensorial quality enhancement of Nile tilapia fillets. Int. J. Biol. Macromol. 2017, 99, 499-505. [CrossRef]

174. Viji, P.; Panda, S.K.; Mohan, C.O.; Bindu, J.; Ravishankar, C.N.; Srinivasa Gopal, T.K. Combined effects of vacuum packaging and mint extract treatment on the biochemical, sensory and microbial changes of chill stored Indian mackerel. J. Food Sci. Technol. 2016, 53, 4289-4297. [CrossRef]

175. Raeisi, S.; Ojagh, S.M.; Sharifi-Rad, M.; Sharifi-Rad, J.; Quek, S.Y. Evaluation of Allium paradoxum (M.B.) G. Don. and Eryngium caucasicum trauve. Extracts on the shelf-life and quality of silver carp (Hypophthalmichthys molitrix) fillets during refrigerated storage. J. Food Safety 2017, 37, e12321. [CrossRef] 
176. Mazandrani, H.A.; Javadian, S.; Bahram, S. The effect of encapsulated fennel extracts on the quality of silver carp fillets during refrigerated storage. Food Sci. Nutr. 2016, 4, 298-304. [CrossRef] [PubMed]

177. Alp Erbay, E.; Dağtekin, B.B.; Türe, M.; Yeşilsu, A.F.; Torres-Giner, S. Quality improvement of rainbow trout fillets by whey protein isolate coatings containing electrospun poly( $\varepsilon$-caprolactone) nanofibers with Urtica dioica L. extract during storage. LWT-Food Sci. Technol. 2017, 78, 340-351. [CrossRef]

178. Zhuang, S.; Li, Y.; Jia, S.; Hong, H.; Liu, Y.; Luo, Y. Effects of pomegranate peel extract on quality and microbiota composition of bighead carp (Aristichthys nobilis) fillets during chilled storage. Food Microbiol. 2019, 82, 445-454. [CrossRef] [PubMed]

179. Baghlani, N.; Hosseini, S.M.; Jafarpour, S.A.; Mousavi, S.M.; Khodanazary, A. Effect of carboxymethyl cellulose edible coating enriched with summer savory extract on quality parameters of Spangled emperor (Lethrinus nebulosus) fillets during refrigerated storage. J. Packag. Technol. Res. 2019. [CrossRef]

180. Sousa, W.M.; Silva, R.O.; Bezerra, F.F.; Bingana, R.D.; Barros, F.C.N.; Costa, L.E.C.; Sombra, V.G.; Soares, P.M.G.; Feitosa, J.P.A.; Paula, R.C.M.D. Sulfated polysaccharide fraction from marine algae Solieria filiformis: Structural characterization, gastroprotective and antioxidant effects. Carbohyd. Polym. 2016, 152, 140-148. [CrossRef] [PubMed]

181. Pane, G.; Cacciola, G.; Giacco, E.; Mariottini, G.L.; Coppo, E. Assessment of the antimicrobial activity of algae extracts on bacteria responsible of external otitis. Mar. Drugs 2015, 13, 6440-6452. [CrossRef]

182. Wang, J.H.; Xu, J.L.; Zhang, J.C.; Liu, Y.; Sun, H.J.; Zha, X. Physicochemical properties and antioxidant activities of polysaccharide from floral mushroom cultivated in Huangshan Mountain. Carbohyd. Polym. 2015, 131, 240-247. [CrossRef]

183. Smolskaite, L.; Venskutonis, P.R.; Talou, T. Comprehensive evaluation of antioxidant and antimicrobial properties of different mushroom species. LWT-Food Sci. Technol. 2015, 60, 462-471. [CrossRef]

184. Heleno, S.A.; Barros, L.; Martins, A.; Morales, P.; Fernández-Ruiz, V.; Glamoclija, J.; Sokovic, M.; Ferreira, I.C.F.R. Nutritional value, bioactive compounds, antimicrobial activity and bioaccessibility studies with wild edible mushrooms. LWT-Food Sci. Technol. 2015, 63, 799-806. [CrossRef]

185. Pinapérez, M.C.; Rivas, A.; Martínez, A.; Rodrigo, D. Antimicrobial potential of macro and microalgae against pathogenic and spoilage microorganisms in food. Food Chem. 2017, 235, 34-44. [CrossRef]

186. Shen, H.S.; Shao, S.; Chen, J.C.; Zhou, T. Antimicrobials from mushrooms for assuring food safety. Compr. Rev. Food Sci. Food Safety 2017, 16, 316-329. [CrossRef]

187. Watson, S.B.; Cruz-Rivera, E. Algal chemical ecology: An introduction to the special issue. Phycologia 2003, 42, 319-323. [CrossRef]

188. Wang, Y.; Xu, Z.; Bach, S.J.; Mcallister, T.A. Sensitivity of Escherichia coli to seaweed (Ascophyllum nodosum) phlorotannins and terrestrial tannins. Asian Austral. J. Anim. 2009, 22, 238-245. [CrossRef]

189. Amorim, R.D.N.D.S.; Rodrigues, J.A.G.; Holanda, M.L.; Quinderé, A.L.G.; Paula, R.C.M.D.; Melo, V.M.M.; Benevides, N.M.B. Antimicrobial effect of a crude sulfated polysaccharide from the red seaweed Gracilaria ornata. Braz. Arch. Biol. Technol. 2012, 55, 171-181. [CrossRef]

190. Bala, N.; Aitken, E.A.; Cusack, A.; Steadman, K.J. Antimicrobial potential of Australian macrofungi extracts against foodborne and other pathogens. Phytother. Res. 2012, 26, 465-469. [CrossRef] [PubMed]

191. Borah, B.; Phukon, P.; Hazarika, M.P.; Ahmed, R.; Sarmah, D.K.; Wann, S.B.; Das, A.; Bhau, B.S. Calamus leptospadix Griff. a high saponin yielding plant with antimicrobial property. Ind. Crop. Prod. 2016, 82, 127-132. [CrossRef]

192. Alcázar, M.; Kind, T.; Gschaedler, A.; Silveria, M.; Arrizon, J.; Fiehn, O.; Vallejo, A.; Higuera, I.; Lugo, E. Effect of steroidal saponins from Agave on the polysaccharide cell wall composition of Saccharomyces cerevisiae and Kluyveromyces marxianus. LWT-Food Sci. Technol. 2017, 77, 430-439. [CrossRef]

193. Ribeiro, B.D.; Alviano, D.S.; Barreto, D.W.; Coelho, M.A.Z. Functional properties of saponins from sisal (Agave sisalana) and juá (Ziziphus joazeiro): Critical micellar concentration, antioxidant and antimicrobial activities. Colloids Surf. A Physicochem. Eng. Asp. 2013, 436, 736-743. [CrossRef]

194. Ahmad, A.; Kaleem, M.; Ahmed, Z.; Shafiq, H. Therapeutic potential of flavonoids and their mechanism of action against microbial and viral infections-A review. Food Res. Int. 2015, 77, 221-235. [CrossRef]

195. Tripoli, E.; Guardia, M.L.; Giammanco, S.; Majo, D.D.; Giammanco, M. Citrus flavonoids: Molecular structure, biological activity and nutritional properties: A review. Food Chem. 2007, 104, 466-479. [CrossRef]

196. Seleem, D.; Pardi, V.; Murata, R.M. Review of flavonoids: A diverse group of natural compounds with anti-Candida albicans activity in vitro. Arch. Oral Biol. 2017, 76, 76-83. [CrossRef] [PubMed] 
197. Xie, Y.; Yang, W.; Tang, F.; Chen, X.; Ren, L. Antibacterial activities of flavonoids: Structure-activity relationship and mechanism. Curr. Med. Chem. 2014, 22, 132-149. [CrossRef] [PubMed]

198. Zheng, Z. Ingredient technology for food preservation. Ind. Biot. 2014, 10, 28-33. [CrossRef]

199. Ford, L.S.; Taylor, S.L.; Pacenza, R.; Niemann, L.M.; Lambrecht, D.M.; Sicherer, S.H. Food allergen advisory labeling and product contamination with egg, milk, and peanut. J. Allergy Clin. Immun. 2010, 126, 384-385. [CrossRef] [PubMed]

200. Tikhonov, V.E.; Stepnova, E.A.; Babak, V.G.; Yamskov, I.A.; Palma-Guerrero, J.; Jansson, H.B.; Lopez-Llorca, L.V.; Salinas, J.; Gerasimenko, D.V.; Avdienko, I.D. Bactericidal and antifungal activities of a low molecular weight chitosan and its N-/2(3)-(dodec-2-enyl)succinoyl/-derivatives. Carbohyd. Polym. 2006, 64, 66-72. [CrossRef]

201. Zou, P.; Yang, X.; Wang, J.; Li, Y.; Yu, H.; Zhang, Y.; Liu, G. Advances in characterisation and biological activities of chitosan and chitosan oligosaccharides. Food Chem. 2016, 190, 1174-1181. [CrossRef] [PubMed]

202. Divya, K.; Smitha, V.; Jisha, M.S. Antifungal, antioxidant and cytotoxic activities of chitosan nanoparticles and its use as an edible coating on vegetables. Int. J. Biol. Macromol. 2018, 114, 572-577. [CrossRef] [PubMed]

203. Sharma, N.; Singh, D.; Rani, R.; Sharma, D.; Pandey, H.; Agarwal, V. Chapter 13—Chitosan and Its Nanocarriers: Applications and Opportunities. In Nanomaterials in Plants, Algae and Microorganisms; Tripathi, D.K., Ahmad, P., Sharma, S., Chauhan, D.K., Dubey, N.K., Eds.; Academic Press: Cambridge, MA, USA, 2019; pp. 267-286.

204. Dutta, P.K.; Shipra, T.; Mehrotra, G.K.; Joydeep, D. Perspectives for chitosan based antimicrobial films in food applications. Food Chem. 2009, 114, 1173-1182. [CrossRef]

205. Friedman, M.; Juneja, V.K. Review of antimicrobial and antioxidative activities of chitosans in food. J. Food Protect. 2010, 73, 1737-1761. [CrossRef]

206. Zhang, H.; Li, R.; Liu, W. Effects of chitin and its derivative chitosan on postharvest decay of fruits: A review. Int. J. Mol. Sci. 2011, 12, 917-934. [CrossRef]

207. No, H.K.; Meyers, S.P.; Prinyawiwatkul, W.; Xu, Z. Applications of chitosan for improvement of quality and shelf life of foods: A review. J. Food Sci. 2007, 72, R87-R100. [CrossRef] [PubMed]

208. Aider, M. Chitosan application for active bio-based films production and potential in the food industry: Review. LWT-Food Sci. Technol. 2010, 43, 837-842. [CrossRef]

209. Mujtaba, M.; Morsi, R.E.; Kerch, G.; Elsabee, M.Z.; Kaya, M.; Labidi, J.; Khawar, K.M. Current advancements in chitosan-based film production for food technology: A review. Int. J. Biol. Macromol. 2019, 121, 889-904. [CrossRef] [PubMed]

210. Wang, H.; Qian, J.; Ding, F. Emerging chitosan-based films for food packaging applications. J. Agric. Food Chem. 2018, 66, 395-413. [CrossRef] [PubMed]

211. US Food and Drug Administration. Direct food substances affirmed as generally recognized as safe; egg white lysozyme. Fed. Regist. Vol. 1998, 63, 12421-12426.

212. Ercan, D.; Demirci, A. Recent advances for the production and recovery methods of lysozyme. Crit. Rev. Biotechnol. 2015, 36, 1078-1088. [CrossRef] [PubMed]

213. Rawdkuen, S.; Suthiluk, P.; Kamhangwong, D.; Benjakul, S. Antimicrobial activity of some potential active compounds against food spoilage microorganisms. Afr. J. Biotechnol. 2012, 11, 13914-13921. [CrossRef]

214. Güçbilmez, Ç.M.; Yemenicioğlu, A.; Arslanoğlu, A. Antimicrobial and antioxidant activity of edible zein films incorporated with lysozyme, albumin proteins and disodium EDTA. Food Res. Int. 2007, 40, 80-91. [CrossRef]

215. Datta, S.; Janes, M.E.; Xue, Q.G.; Losso, J.; La Peyre, J.F. Control of Listeria monocytogenes and Salmonella anatum on the surface of smoked salmon coated with calcium alginate coating containing oyster lysozyme and nisin. J. Food Sci. 2008, 73, M67-M71. [CrossRef]

216. Shi, J.B.; Xie, J.; Gao, Z.L.; Li, L.; Xiong, Q.; He, R. Effects of tea polyphenols, lysozyme and chitosan on improving preservation quality of pomfret fillet. Adv. Mater. Res. 2013, 781, 1582-1588. [CrossRef]

217. Wu, T.; Ge, Y.; Li, Y.; Xiang, Y.; Jiang, Y.; Hu, Y. Quality enhancement of large yellow croaker treated with edible coatings based on chitosan and lysozyme. Int. J. Biol. Macromol. 2018, 120, 1072-1079. [CrossRef] [PubMed]

218. Wang, Z.; Hu, S.; Gao, Y.; Ye, C.; Wang, H. Effect of collagen-lysozyme coating on fresh-salmon fillets preservation. LWT-Food Sci. Technol. 2017, 75, 59-64. [CrossRef] 
219. GóMezguilléN, M.C.; PéRezmateos, M.; GóMezestaca, J.; LóPezcaballero, E.; GiméNez, B.; Montero, P. Fish gelatin: A renewable material for developing active biodegradable films. Trends Food Sci. Technol. 2009, 20, 3-16. [CrossRef]

220. Wang, B.; Timilsena, Y.P.; Blanch, E.; Adhikari, B. Mild thermal treatment and in-vitro digestion of three forms of bovine lactoferrin: Effects on functional properties. Int. Dairy J. 2017, 64, 22-30. [CrossRef]

221. Barbiroli, A.; Bonomi, F.; Capretti, G.; Iametti, S.; Manzoni, M.; Piergiovanni, L.; Rollini, M. Antimicrobial activity of lysozyme and lactoferrin incorporated in cellulose-based food packaging. Food Control 2012, 26, 387-392. [CrossRef]

222. Farnaud, S.; Evans, R.W. Lactoferrin-A multifunctional protein with antimicrobial properties. Mol. Immunol. 2003, 40, 395-405. [CrossRef]

223. Eslamloo, K.; Falahatkar, B.; Yokoyama, S. Effects of dietary bovine lactoferrin on growth, physiological performance, iron metabolism and non-specific immune responses of Siberian sturgeon Acipenser baeri. Fish Shellfish Immun. 2012, 32, 976-985. [CrossRef]

224. Cecchini, S.; Caputo, A.R. Potential use of bovine lactoferrin as adjuvant for the modulation of the specific immune response in rainbow trout (Oncorhynchus mykiss W.). Aquacult. Int. 2016, 25, 223-232. [CrossRef]

225. Khuyen, T.D.; Snm, M.; Cornet, V.; Douxfils, J.; Betoulle, S.; Bossier, P.; Reyes-López, F.E.; Tort, L.; Kestemont, P. Physiological and immune response of juvenile rainbow trout to dietary bovine lactoferrin. Fish Shellfish Immun. 2017, 71, 359-371. [CrossRef]

226. Rostami, H.; Abbaszadeh, S.; Shokri, S. Combined effects of lactoperoxidase system-whey protein coating and modified atmosphere packaging on the microbiological, chemical and sensory attributes of Pike-Perch fillets. J. Food Sci. Technol. 2017, 54, 3243-3250. [CrossRef]

227. Ehsani, A.; Hashemi, M.; Aminzare, M.; Raeisi, M.; Afshari, A.; Mirza Alizadeh, A.; Rezaeigolestani, M. Comparative evaluation of edible films impregnated with sage essential oil or lactoperoxidase system: Impact on chemical and sensory quality of carp burgers. J. Food Process. Preserv. 2019, 43, e14070. [CrossRef]

228. Min, S.; Krochta, J.M.; Rumsey, T.R. Diffusion of thiocyanate and hypothiocyanite in whey protein films incorporating the lactoperoxidase system. J. Food Eng. 2007, 80, 1116-1124. [CrossRef]

229. Shariat, S.S.; Jafari, N.; Tavakoli, N.; Najafi, R.B. Protection of lactoperoxidase activity with sugars during lyophilization and evaluation of its antibacterial properties. Res. Pharm. Sci. 2015, 10, 152-160. [PubMed]

230. Jasour, M.S.; Ehsani, A.; Mehryar, L.; Naghibi, S.S. Chitosan coating incorporated with lactoperoxidase system: An active edible coating for fish preservation. J. Sci. Food Agric. 2015, 95, 1373-1378. [CrossRef] [PubMed]

231. Shokri, S.; Ehsani, A.; Jasour, M.S. Efficacy of lactoperoxidase system-whey protein coating on shelf-life extension of rainbow trout fillets during cold storage $\left(4^{\circ} \mathrm{C}\right)$. Food Bioprocess Technol. 2015, 8, 54-62. [CrossRef]

232. Socaciu, M.-I.; Semeniuc, C.A.; Vodnar, D.C. Edible films and coatings for fresh fish packaging: Focus on quality changes and shelf-life extension. Coatings 2018, 8, 366. [CrossRef]

233. Shokri, S.; Ehsani, A. Efficacy of whey protein coating incorporated with lactoperoxidase and $\alpha$-tocopherol in shelf life extension of Pike-Perch fillets during refrigeration. LWT-Food Sci. Technol. 2017, 85, 225-231. [CrossRef]

234. Montiel, R.; Bravo, D.; Alba, M.D.; Gaya, P.; Medina, M. Combined effect of high pressure treatments and the lactoperoxidase system on the inactivation of Listeria monocytogenes in cold-smoked salmon. Innov. Food Sci. Emerg. 2012, 16, 26-32. [CrossRef]

235. Sharifi, F.; Khanzadi, S.; Hashemi, M.; Azizzadeh, M. Control of Listeria monocytogenes and Escherichia coli O157: H7 inoculated on fish fillets using alginate coating containing lactoperoxidase system and Zataria multiflora Boiss essential oil. J. Aquat. Food Prod. Technol. 2017, 26, 1014-1021. [CrossRef]

(C) 2019 by the authors. Licensee MDPI, Basel, Switzerland. This article is an open access article distributed under the terms and conditions of the Creative Commons Attribution (CC BY) license (http://creativecommons.org/licenses/by/4.0/). 